\title{
Electrical Impedance Spectroscopic Studies on Broiler Chicken Tissue Suitable for the Development of Practical Phantoms in Multifrequency EIT
}

\author{
Tushar Kanti Bera and J. Nagaraju \\ 1. Department of Instrumentation and Applied Physics, Indian Institute of Science, Bangalore - 560012, India \\ 2.E-mail any correspondence to: solarjnr@isu.iisc.ernet.in
}

\begin{abstract}
Phantoms are essential for assessing the system performance in Electrical Impedance Tomography (EIT). Saline phantoms with insulator inhomogeneity fail to mimic the physiological structure of real body tissue in several aspects. Saline or any other salt solution is purely resistive and hence studying multifrequency EIT systems cannot be assessed with saline phantoms because the response of the purely resistive materials do not change over frequency. Animal tissues show a variable response over a wide band of signal frequency due to their complex physiological and physiochemical structures and hence they can be suitably used as bathing medium and inhomogeneity in the phantoms of multifrequency EIT systems. An efficient assessment of a multifrequency EIT system with a real tissue phantom needs a prior knowledge of the impedance profile of the bathing medium as well as the inhomogeneity. In this direction Electrical Impedance Spectroscopy (EIS) studies on broiler chicken muscle tissue paste, muscle tissue blocks and fat tissue blocks are conducted over a wide range of signal frequency using impedance analyzers, and their impedance profiles are analyzed. Results show that the chicken muscle tissue paste is less resistive than the fat tissue and hence it can be used successfully as the bathing medium of the phantoms for impedance imaging in multifrequency EIT. Fat tissue is found more resistive than the muscle tissue which makes it more suitable for the inhomogeneity in phantoms of impedance imaging study. Moreover, as there is a large difference between the resistivities of muscle tissue and fat tissue they can be used as either inhomogeneity or background medium. EIS studies also show that the variations in the impedance parameters of a muscle tissue block are greater than in the tissue paste as the cell membrane structures are destroyed in tissue paste. Results also show that the $\alpha$ and $\beta$ dispersions are visible in all the parameters of both the tissue samples, but both the dispersions are larger in the muscle tissue block. The Nyquist plot obtained for the muscle tissue block demonstrates that the equivalent electric model of the tissue sample contains Warburg impedance and a constant phase element.
\end{abstract}

Keywords: broiler chicken tissue, bioelectrical impedance analysis (BIA), electrical impedance spectroscopy (EIS), multifrequency electrical impedance tomography, real tissue phantoms.

\section{Introduction}

Practical phantoms [1-10] are essential for assessing the system performance in Electrical Impedance Tomography (EIT) [11-16] for its validation, calibration and comparison purposes. Practical phantom studies are also essential for assessing the EIT-instrumentation [17-18] and EIT reconstruction algorithms [19-21]. Saline phantoms with insulator inhomogeneities have their own limitations as they could not mimic the physiological structure of real body tissue in several aspects. Saline or any other salt solutions are purely resistive materials and hence the multifrequency EIT systems [1, 22-24] cannot be studied properly with saline phantoms because the responses of the purely resistive materials do not change over frequency. On the other hand, electrical impedance of biological materials is a complex quantity [25-26] which is a function of tissue composition as well as the frequency of the applied ac signal [27]. The Protein-Lipid-Protein structure [28] of the membrane of a biological cell gives a cell capacitance whereas the extracellular fluid, cytoplasm and nucleus contributes to the cell resistance [29]. As a result, animal tissues and plant tissues show a variable response over a wide band of signal frequency due to their complex physiological and physiochemical structures, and hence they can suitably be used as bathing medium [1-2] and inhomogeneity in the phantoms of a multifrequency EIT system. A proper assessment of a multifrequency EIT system with a real tissue phantom needs a prior knowledge of the impedance profile of the bathing medium as well as the inhomogeneity. In this direction, bioelectrical impedance analysis (BIA) [29-32] of broiler chicken muscle tissue paste and fat tissue is conducted by electrical impedance spectroscopy (EIS) [33-42] and their impedance profiles are thoroughly studied. EIS of broiler chicken muscle tissue paste, chicken tissue blocks and chicken fat tissue is conducted using a constant current signal with a wide frequency range using impedance analyzers. Results show that the broiler chicken muscle tissue is less resistive than the fat tissue and hence it can be successfully used as the bathing medium of the phantoms for impedance imaging in multifrequency EIT. On the other hand, the fat tissue is found more resistive than the muscle tissue which makes it more suitable for the inhomogeneity in phantoms of impedance imaging study. Moreover, as there is a sufficient difference between the resistivities of muscle tissue and fat tissue they can be used as either inhomogeneity or background medium. EIS studies show that all the impedance parameters of the chicken tissue samples are functions of frequency and hence they are suitable for use as phantom materials in multifrequency EIT. 


\section{Materials and Methods}

\section{Electrical Impedance Spectroscopy of the Chicken Tissues}

Electrical impedance spectroscopy is an electrical impedance analyzing technique in which the complex electrical impedance $(Z)$ and its phase angle $(\theta)$ of an object under test are measured at different frequency points within a specified frequency band, from the measured potentials (V) developed by injecting a constant sinusoidal current signal (I) to the object, using a two-electrode or fourelectrode method (Fig.-1a). In four-electrode technique (Fig.-1b) of impedance measurement, a constant alternating current is injected through two electrodes (called current electrodes: blue electrodes in Fig.- 1b) and the ac potential developed across two points of the body part under test is measured on other two electrodes (called voltage electrodes: red electrodes in Fig.-1b). Dividing the voltage measurement by the applied current, the complex transfer impedance is estimated.
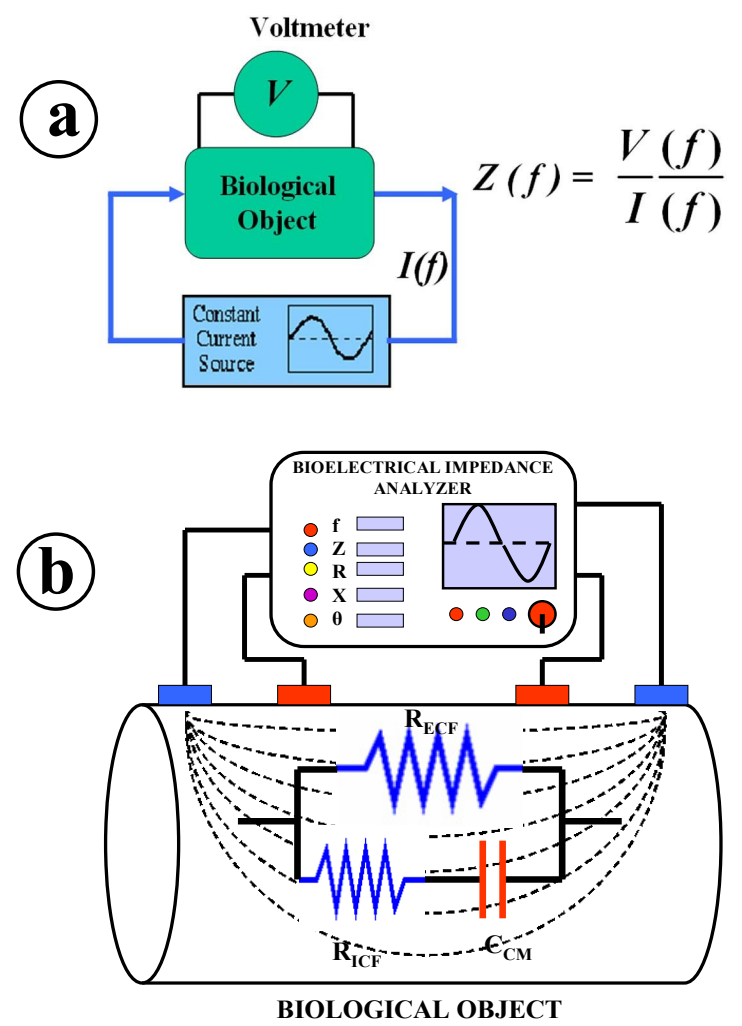

Figure-1: (a) A schematic of electrical impedance measurement, (b) four electrode measurement of electrical transfer impedance.

On the contrary, in the two-electrode method the current injection and voltage measurement are made using the same electrodes and hence it is known as two-electrode technique. In EIS a constant current signal of variable frequency is applied to the object under test and the potentials developed across the measurement points at each frequency are measured. For a single frequency measurement, complex impedance $(\mathrm{Z})$ is a function of material properties which create a phase displacement $(\theta)$ between $I$ and $V$. In impedance spectroscopy, $Z$ and $\theta$ are the functions of material properties at each frequency and hence they are the functions of frequency also. To analyze the EIS data, in present study, the real part of $Z(R)$ and imaginary part of $\mathrm{Z}(\mathrm{X})$ at each frequency points are calculated and plotted (along $\mathrm{x}$-axis and $\mathrm{y}$-axis respectively) to obtain the Nyquist Plot (plot of imaginary part of $Z$ versus real part of Z) or R-X spectrum. Any material can be modeled as a combination of electrical circuit elements (as each material has their own electrical properties like resistance $\left(R_{e}\right)$, capacitance $\left(C_{e}\right)$, inductance $\left(L_{e}\right)$ etc. $)$. Hence, the frequency responses of different circuit elements (resistor, inductor, capacitor etc.) or their combinations are different and hence their corresponding Nyquist plots are different from each other (Fig.-2a-f).

Similarly, biological tissues can also be modeled as the combination of different circuit elements contributing to its complex bioelectrical impedance $(Z)$. Electrical impedance of biological tissues consist of resistive and capacitive components (for low frequency the magnetic behavior is neglected [43-44]), which are functions of signal frequency giving rise to a frequency dependent complex bioelectrical impedance defined as:

$Z(\omega)=\operatorname{Re}(Z(\omega))-j \operatorname{Im}(Z(\omega))=R(\omega)-j X(\omega)$

where $\operatorname{Re}(Z(\omega))=R$ represents the magnitude of the real part of complex $Z$ and $\operatorname{Im}(Z(\omega))=X$ represents the magnitude of the imaginary part of the complex $Z$.

In biological cells, the cytoplasm, nucleus and extracellular fluids form a purely resistive path (with a good electrical conductivity) to the current signal [45]. On the other hand, the cell membranes (Fig.-3a) are composed of electrically non-conducting lipid bi-layers sandwiched between two conducting protein layers (Fig.-3a) and hence it provides a capacitance [45]. Cytoplasm and the nucleus are mostly made up of solutions of proteins, different chemicals and salts, which are electrically conducting materials. Hence intercellular fluid (ICF) containing the cytoplasm and nucleus offers a resistive path $\left(\mathrm{R}_{\mathrm{ICF}}\right)$ to the electric signal (Fig.-1b). The cell membrane (CM) consists of a layer of non-conductive lipid material sandwiched between two layers of conductive protein molecules. Hence it behaves like a capacitance $\left(\mathrm{C}_{\mathrm{CM}}\right)$ contributing a capacitive reactance to an alternating current path (Fig.-1b). Being made up of conducting solution extracellular fluid (ECF) also creates a resistive path $\left(\mathrm{R}_{\mathrm{ECF}}\right)$ towards the electric signal (Fig.-1b). Hence, the equivalent electrical circuit of an isolated animal cell consists of the parallel combination of extracellular resistance and the intracellular impedance where intracellular impedance is introduced due to the series combination of the membrane capacitance and the protoplasm (cytoplasm + nucleus) resistance (Fig.-1b). Biological tissue is made up of a three-dimensional array of cells and hence, depending on the tissue composition and structure, the bioimpedance profile changes from tissue to tissue. Moreover, as the frequency changes, the tissue impedance and its phase angle are varied with a corresponding change in its real (R) and imaginary (X) parts. 

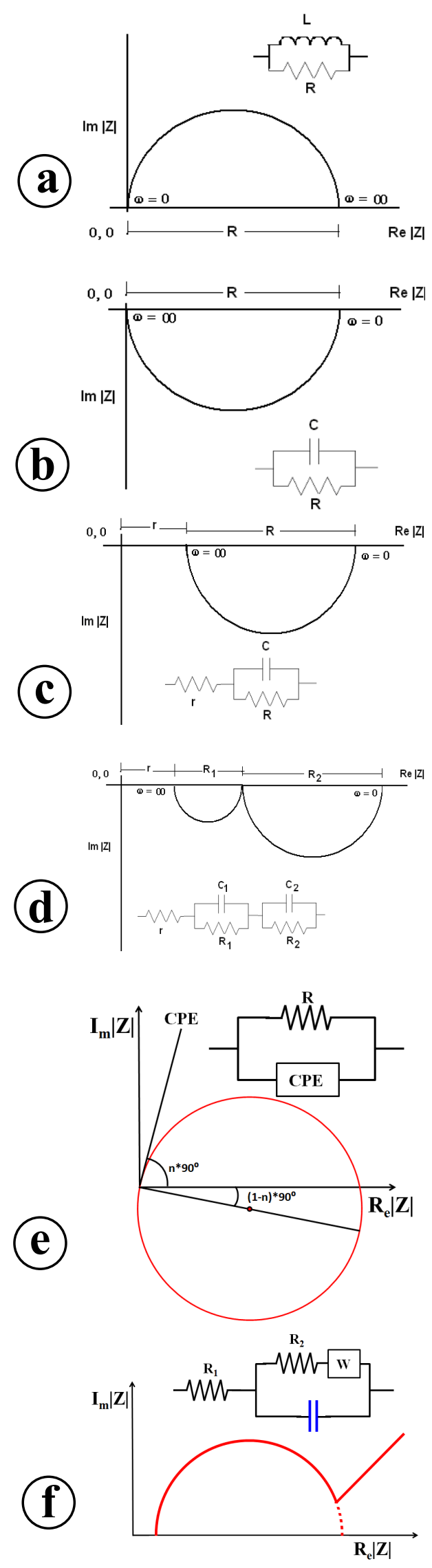

Figure-2: Nyquist plots for different circuit combinations: (a) $\mathrm{R}$ and $\mathrm{L}$ in parallel, (b) $\mathrm{R}$ and $\mathrm{C}$ in parallel, (c) $\mathrm{r}$ in series with ( $\mathrm{R}$ and $\mathrm{C}$ in parallel), (d) $\mathrm{r}$ in series with ( $\mathrm{R}$ and $\mathrm{C}$ in parallel) and ( $\mathrm{R}$ and $\mathrm{C}$ in parallel), (e) $\mathrm{R}$ and CPE in parallel, (f) $\mathrm{R}_{1}$ in series with the parallel combinations of $\left(\mathrm{R}_{2}\right.$ in series with $\left.\mathrm{W}\right)$ and $\mathrm{C}$.
In bioimpedance spectroscopy, a sinusoidal constant current (with varying frequency of particular range) is injected to the biological object under test through the current electrodes and the voltage developed across a particular domain is measured (Fig.-1b). The bioimpedance $(Z)$ and its phase angle $(\theta)$ are calculated from the measured data (Fig.-1a). $Z$ and $\theta$ are functions of body compositions as well as the signal frequency $(\omega=2 \pi \mathrm{f})$. The frequency responses of $Z(\omega), \theta(\omega), R(\omega)$ and $X(\omega)$ and other parameters are studied. The reactive part of the complex bioelectrical impedance is generally of the capacitive type as the inductive response of biological tissues at low frequency is negligible [43-44]. According to the tissue properties the magnitude of $Z(\omega), \theta(\omega), R(\omega)$ and $X(\omega)$ are changed with a change in frequency and hence the nature and behavior of the biological tissues can be easily distinguished by plotting the impedance parameters with respect to the signal frequency. Electrical impedance spectroscopy of chicken muscle tissue paste, muscle tissue blocks and fat tissue is conducted and the variations of $Z(\omega), \theta(\omega), R(\omega), X(\omega)$, resistivity $(\rho(\omega))$, conductivity $(\sigma(\omega)), C(\omega)$, permittivity $(\varepsilon)$ and relative permittivity $\left(\varepsilon_{\mathrm{r}}\right)$ over frequency are studied.

\section{Sample Preparation}

Broiler chicken muscle tissues and fat tissues are collected from the market and cut in small pieces after removing all the bones carefully. Muscle and fat tissues are separately rinsed three times with deionized (DI) water (processed and purified by Millipore Synergy UV Water Purification System with a high accuracy (output water resistivity $=18$ $\left.\times 10^{6} \Omega \mathrm{cm}\right)$ ). Cleaned and wet tissues are kept in two separate funnels covered with blotting papers and the external tissue water is filtered and extracted. All the tissues are kept open on Petri dishes for 30 minutes for local drying by natural evaporation of external water, if any. $2 \%$ deionized water is added to the chicken muscle pieces and the mixture is crushed for 2 minutes in a mixer grinder (No load speed: $2400 \mathrm{rpm}$ ). $1 \%$ DI water is further added to the mixture and rotated at the same speed for another 2 minutes.

\section{Impedance Spectroscopic Studies of Chicken Tissue}

An electrical impedance measurement set up is developed [21] with a rectangular glass tank $(50 \mathrm{~mm} \times 20 \mathrm{~mm} \times 20$ $\mathrm{mm})$ containing two identical square electrodes $(20 \mathrm{~mm} \times$ $20 \mathrm{~mm}$ ). Electrodes are identically cut from a $0.1 \mathrm{~mm}$ thick type 304 Stainless Steel (SS) sheet and machined to give all the electrodes an approximately equal surface area of 20 $\mathrm{mm} \times 20 \mathrm{~mm}$. High quality (Type 304) SS sheet is used to avoid the localized pitting corrosion leading to the creation of small holes on the electrode surface. The electrodes are connected by low resistive equal length flexible copper wires and the chicken muscle tissue paste obtained is 
transferred carefully in the rectangular glass tank (Fig.-3b). The tank is filled with the chicken tissue paste samples and the electrical impedance spectroscopy is conducted at room temperature with a current signal of $1 \mathrm{~mA}(10 \mathrm{~Hz}$ to 2 $\mathrm{MHz}$ ) using a QuadTech 7600 impedance analyzer. Five chicken muscle tissue samples of identical volume $(50 \mathrm{~mm}$ $\times 20 \mathrm{~mm} \times 20 \mathrm{~mm}$ ) are tested separately within a gap of equal and short time period (time required for a complete scan by QuadTech 7600). Similarly five fat tissue samples of identical geometry $(5 \mathrm{~mm} \times 20 \mathrm{~mm} \times 15 \mathrm{~mm})$ are tested separately within a gap of equal and short time period (time required for a complete scan by QuadTech 7600). The complex electrical impedances $\left(\mathrm{Z}_{\text {Muscle }}\right.$ and $\left.\mathrm{Z}_{\mathrm{Fat}}\right)$ and phase angles $\left(\theta_{\text {Muscle }}\right.$ and $\left.\theta_{\text {Fat }}\right)$ are measured at each frequency using the Quadtech7600 impedance analyzer (Fig.-3c). Real and imaginary parts of the muscle tissue impedance $\left(\mathrm{R}_{\text {Muscle }}\right.$ and $\mathrm{X}_{\text {Muscle }}$ respectively) and fat tissue impedance $\left(\mathrm{R}_{\mathrm{Fat}}\right.$ and $\mathrm{X}_{\mathrm{Fat}}$ respectively) are calculated at each frequency. The variation of all the impedance parameters of chicken muscle tissue ( $Z_{\text {Muscle }}, \theta_{\text {Muscle }}, R_{\text {Muscle }}$ and $X_{\text {Muscle }}$ respectively) and chicken fat tissue $\left(Z_{\text {Fat }}, \theta_{\text {Fat }}, R_{\text {Fat }}\right.$ and $X_{\text {Fat }}$ respectively) are studied over frequency. Muscle tissue resistivity $\left(\rho_{\text {Muscle }}\right)$, muscle tissue conductivity $\left(\sigma_{\text {Muscle }}\right)$, fat tissue resistivity $\left(\rho_{\text {Fat }}\right)$ and fat tissue conductivity $\left(\sigma_{\text {Fat }}\right)$ are also calculated from the real parts of the tissue impedances and plotted over frequency.

For further analysis the EIS of chicken tissue blocks $(15 \mathrm{~mm} \times 20 \mathrm{~mm} \times 20 \mathrm{~mm})$ is conducted (Fig.-3d) and the dielectric dispersions associated with biological tissues in which the relative permittivity decreases with increasing frequency [46], are studied. In general three discrete regions of dispersion can be identified in biological tissues [46]. These are commonly defined as:

$\boldsymbol{\alpha}$ dispersion: $(10 \mathrm{~Hz}<\mathrm{f}<10 \mathrm{kHz})$, which is associated with tissue interfaces such as membranes [46-47].

$\boldsymbol{\beta}$ dispersion: $(100 \mathrm{kHz}<\mathrm{f}<10 \mathrm{MHz})$, which is caused by the polarization of cellular membranes and polarization of protein and other organic macromolecules [46].

$\gamma$ dispersion: ( $\mathrm{f}>10 \mathrm{GHz}$ ), which is caused by the polarization of water molecules [46].

To study the $\alpha$ and $\beta$ dispersions of the chicken muscle tissue blocks and muscle tissue paste samples, EIS is conducted from $40 \mathrm{~Hz}$ to $20 \mathrm{MHz}$ using an Agilent4294A (Fig.-3e) with a $1 \mathrm{~mA}$ constant current signal. The variation of all the impedance parameters of chicken muscle tissue blocks, muscle tissue paste and fat tissue are studied over frequency. Muscle tissue resistivity, muscle tissue conductivity, fat tissue resistivity and fat tissue conductivity are also calculated from the real parts of the tissue impedances and plotted over frequency. Since the phase angle was low, at least above $100 \mathrm{~Hz}$, conductivity was calculated as the inverse of resistivity. Tissue capacitance $\left(\mathrm{C}_{\text {Muscle }}\right)$, permittivity $\left(\varepsilon_{\text {Muscle }}\right)$ and relative permittivity $\left(\varepsilon_{\mathrm{rMuscle}}\right)$ are also calculated and $\alpha$ and $\beta$ dispersions are studied. $\mathrm{C}, \varepsilon$ and $\varepsilon_{\mathrm{r}}$ are also calculated for fat tissue.

\section{Impedance Spectroscopic Study of $\mathrm{KCl}$ Solution}

$\mathrm{KCl}$ solutions are prepared with different concentrations $(0.00 \%, 0.05 \%, 0.10 \%, 0.15 \%, 0.20 \%, 0.25 \%, 0.30 \%$, $0.35 \%, 0.40 \%, 0.50 \%, 1.00 \%$ and $2.00 \%$ ) in $\mathrm{w} / \mathrm{v}$ ratios dissolved in DI water.

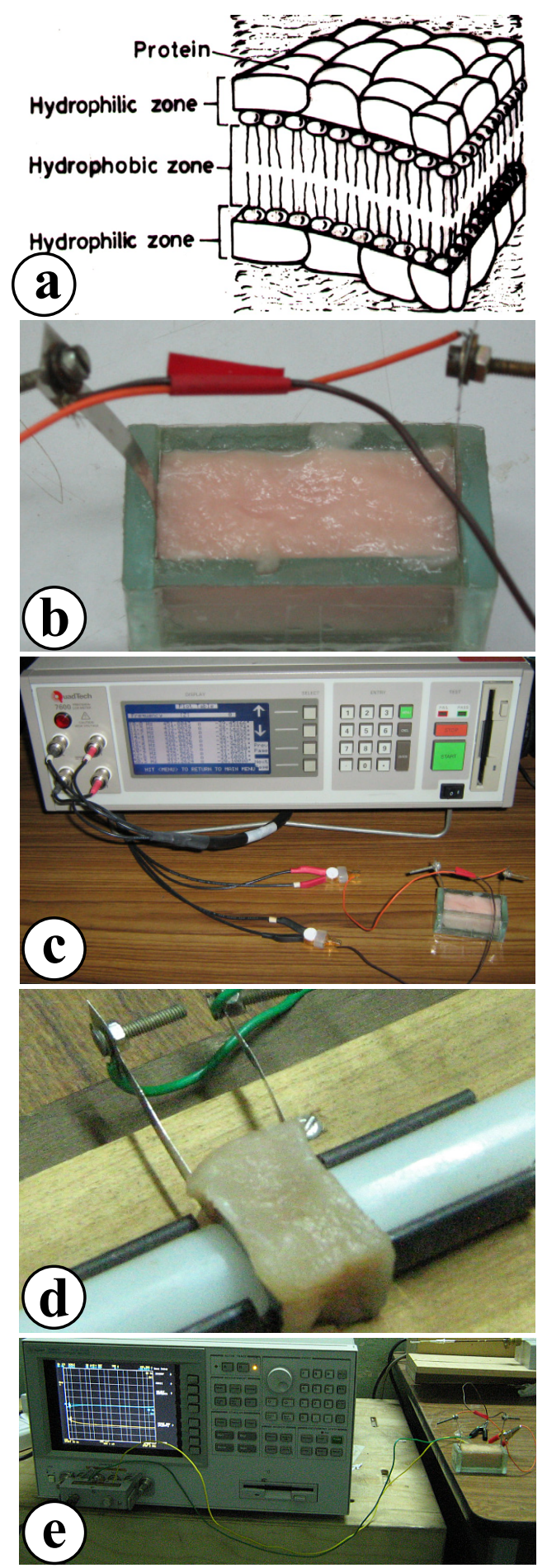

Figure-3: (a) animal cell membrane structure, (b) chicken muscle tissue paste in rectangular glass tank, (c) EIS study of chicken muscle tissue paste using QuadTech7600, (d) chicken muscle tissue block under EIS study using Agilent 4294A, (e) EIS study of chicken muscle tissue paste using Agilent 4294A. 
The $\mathrm{KCl}$ salt samples are separately measured in a high precision weighing machine as per the requirement. The $\mathrm{KCl}$ samples are dissolved in deionized (DI) water (processed and purified by Millipore Synergy UV Water Purification System with a high accuracy (output water resistivity $\left.=18 \times 10^{6} \Omega \mathrm{cm}\right)$ ) and the $\mathrm{KCl}$ solution samples are prepared.

The impedance measurement tank is filled with $\mathrm{KCl}$ solution and EIS is conducted with a current signal of $1 \mathrm{~mA}$ using QuadTech 7600. The EIS study is also conducted for deionized water to study its frequency response as well as the conductivity variation over frequency.

\section{Results}

It is observed that the conductivity of the $\mathrm{KCl}$ solution remains constant for all the frequencies (Fig.-4a). Fig.-4a also shows that the $\mathrm{KCl}$ solutions of different concentration show their individual conductivities which are all constant over frequency. Therefore it is proved that the $\mathrm{KCl}$ solution is purely resistive and hence it is independent of signal frequency. It is also observed that (Fig.-4b) the $\mathrm{KCl}$ solution conductivity $\left(\sigma_{\mathrm{KCl}}\right)$ is a linear function of concentration $\left(\eta_{\mathrm{KCl}}\right)$. Results show that rate of increase of $\sigma_{\mathrm{KCl}}$ at different frequencies is almost the same up to the $\mathrm{KCl}$ concentration of $1 \%$ (Fig.-4b). Beyond the $\mathrm{KCl}$ concentration of $1 \%$, it is observed that the rate of increase of $\sigma_{\mathrm{KCl}}$ reduces slightly due to the higher ion concentration effect (Fig.-4b). It is also observed that, beyond the $\eta_{\mathrm{KCl}}$ of $1 \%$, the rate of increase of $\sigma_{\mathrm{KCl}}$ differs from frequency to frequency up to $100 \mathrm{kHz}$. Beyond $100 \mathrm{kHz}$, the slopes of the $\sigma_{\mathrm{KCl}}$ curves for different frequencies are the same i.e. the rate of increase of $\sigma_{\mathrm{KCl}}$ are the same from $100 \mathrm{kHz}$ to 1 $\mathrm{MHz}$. This is because at the higher frequencies the contact impedance of the electrodes is reduced and ion mobility in the $\mathrm{KCl}$ solution increases.

In the present study, it is to be noted that there is a difference between the geometry of the chicken muscle tissue paste sample (area $=20 \mathrm{~mm} \times 20 \mathrm{~mm}$, length $=50$ $\mathrm{mm}$ ) and the chicken fat tissue sample (area $=20 \mathrm{~mm} \times 15$ $\mathrm{mm}$, length $=5 \mathrm{~mm}$ ). Hence all the impedance parameters depending on the sample length should be understood with a proper scaling.

It is observed that the $Z_{\text {Muscle Paste }}$ (Fig.-5a), $\theta_{\text {Muscle Paste }}$ (Fig.-5b), $\mathrm{R}_{\text {Muscle Paste }}$ (Fig.-5c), $\mathrm{X}_{\text {Muscle Paste }}$ (Fig.-5d), $\mathrm{Z}_{\text {Fat }}$ (Fig.-6a), $\theta_{\text {Fat }}$ (Fig.-6b), $R_{\text {Fat }}$ (Fig.-6c) and $X_{\text {Fat }}$ (Fig.-6d) are

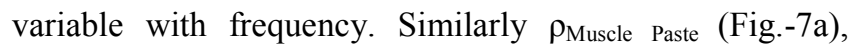
$\sigma_{\text {Muscle Paste }}$ (Fig.-7b), $\rho_{\text {Fat }}$ (Fig.-7c) and $\sigma_{\text {Fat }}$ (Fig.-7d) are variable with frequency. Results show that the variation in $Z_{\text {Muscle Paste }}$ is found between $10 \mathrm{~Hz}-1 \mathrm{kHz}$ where as $Z_{\text {Fat }}$ varies throughout the frequency band $(10 \mathrm{~Hz}-2 \mathrm{MHz})$ with a larger variation between $10 \mathrm{~Hz}-1 \mathrm{kHz}$.

Result show that the variations of $Z_{\text {Muscle Paste }}, \theta_{\text {Muscle Paste, }}$ $\mathrm{R}_{\text {Muscle Paste, }} \mathrm{X}_{\text {Muscle Paste, }} \rho_{\text {Muscle Paste }}$ and $\sigma_{\text {Muscle Paste }}$ are comparatively larger in the low frequency range $(10 \mathrm{~Hz}-1$
$\mathrm{kHz}$ ) whereas their variations are very low after $1 \mathrm{kHz}$. On the other hand the variations of $\mathrm{Z}_{\mathrm{Fat}}, \theta_{\mathrm{Fat}}, \mathrm{R}_{\mathrm{Fat}}, \mathrm{X}_{\mathrm{Fat}}, \rho_{\mathrm{Fat}}$ and $\sigma_{\text {Fat }}$ are found throughout the whole frequency range $(10 \mathrm{~Hz}$ $-2 \mathrm{MHz}$ ) and all of them are comparatively larger than the impedance parameters of the muscle tissue.
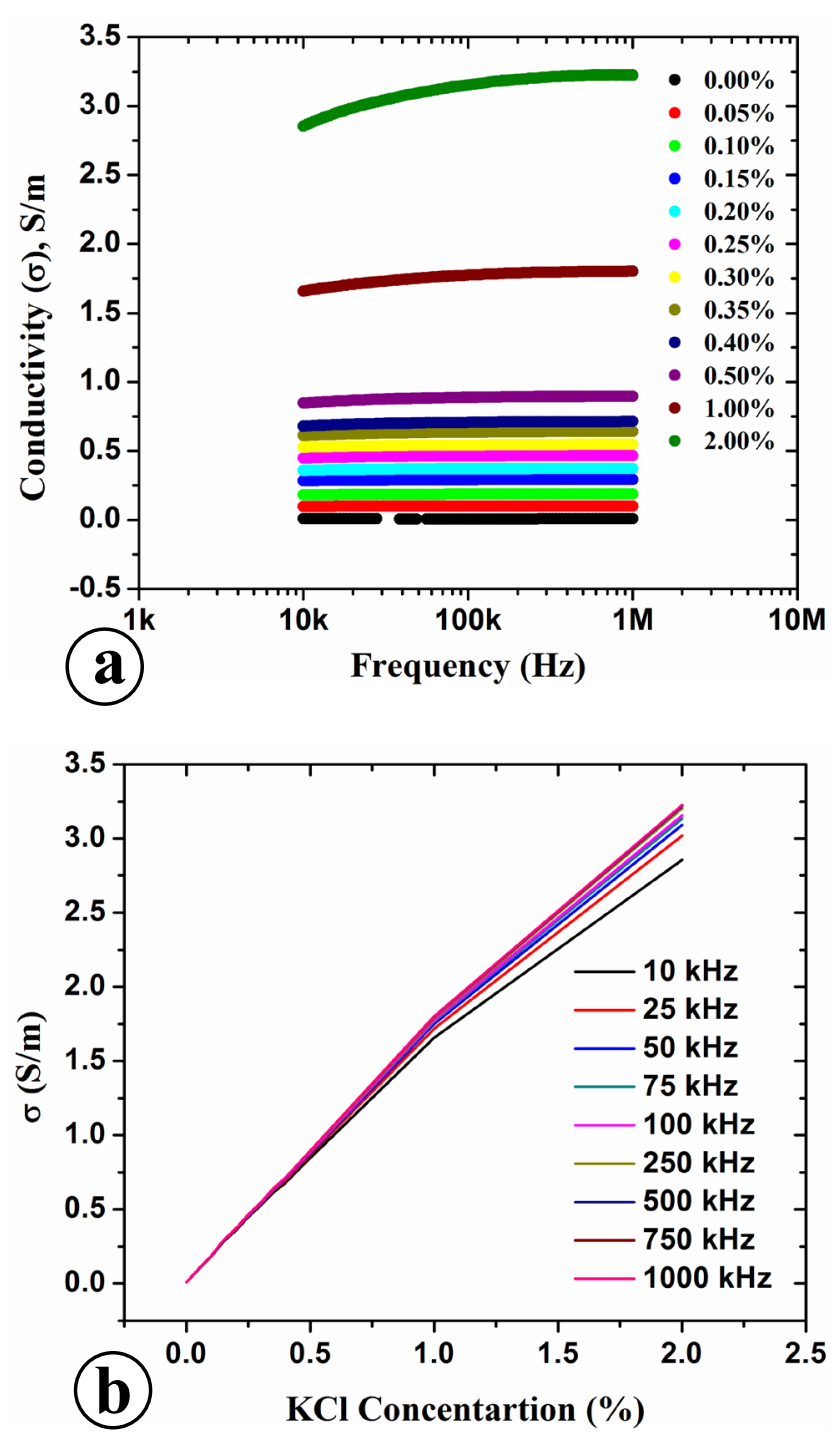

Figure-4: Conductivity profile of $\mathrm{KCl}$ solution (a) variation (over frequency) at different concentration, (b) variation (over concentration) at different frequencies.

It is observed that the sample to sample variations of

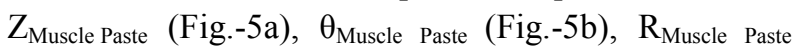
(Fig.-5c), $X_{\text {Muscle Paste (Fig.-5d) are comparatively lower }}$ than the corresponding variations in the $Z_{\text {Fat }}$ (Fig.-6a), $\theta_{\text {Fat }}$ (Fig.-6b), $R_{\text {Fat }}$ (Fig.-6c) and $X_{\text {Fat }}$ (Fig.-6d). Similarly the variations in $\rho_{\text {Muscle Paste }}$ (Fig.-7a) and $\sigma_{\text {Muscle Paste }}$ (Fig.-7b) are comparatively lower than the $\rho_{\text {Fat }}$ (Fig.-7c) and $\sigma_{\text {Fat }}$ (Fig.-7d). It is observed that at $10 \mathrm{~Hz}$ the $\mathrm{Z}_{\text {Muscle }}$ Paste varies (electrode to electrode variations) from $445.01 \Omega$ to $465.54 \Omega$ (Table-1) whereas the $Z_{\text {Fat }}$ varies from $1168.15 \Omega$ to $1065.09 \Omega$ (Table-1). 

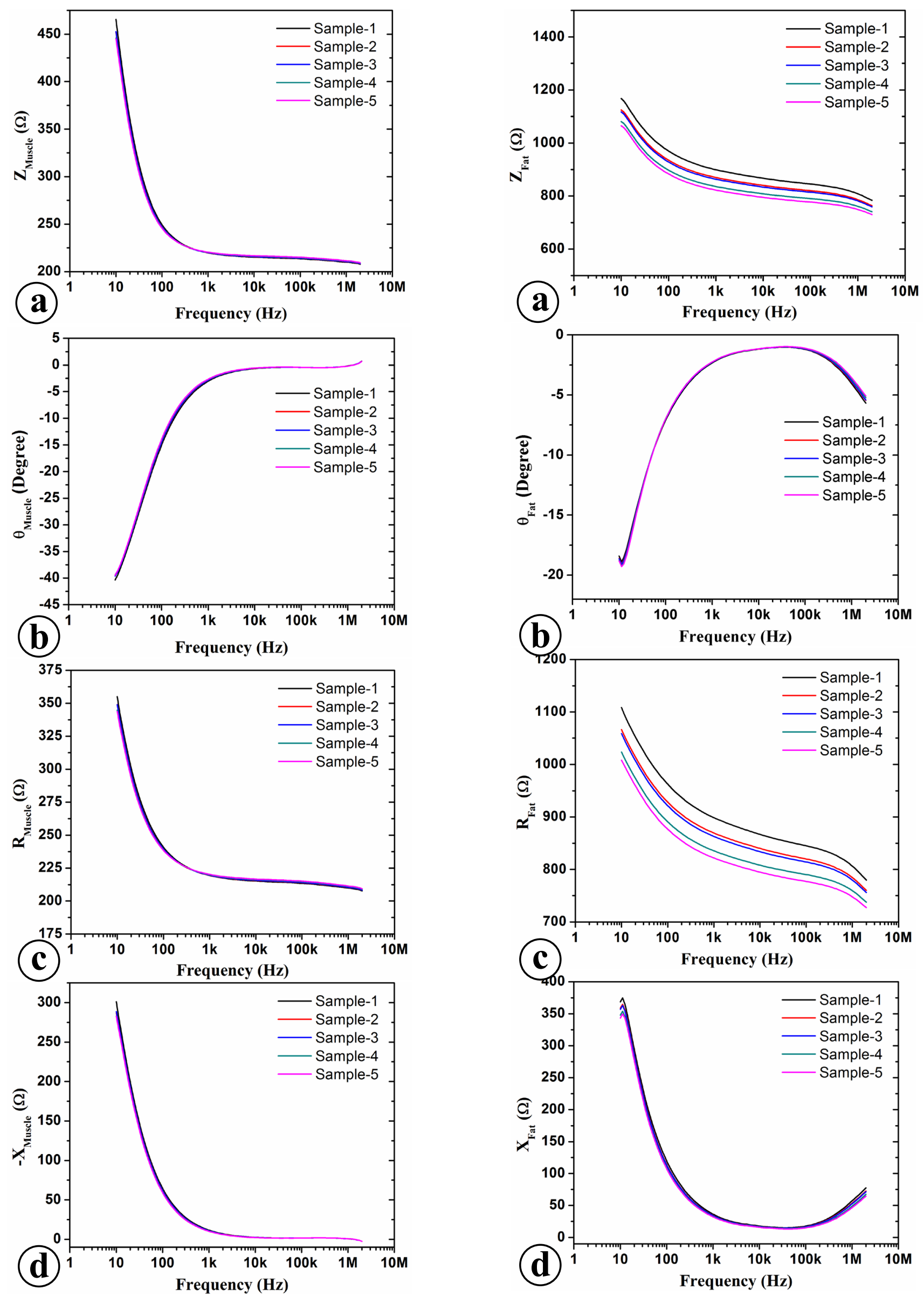

Figure-5: Variation of impedance parameters of chicken tissue

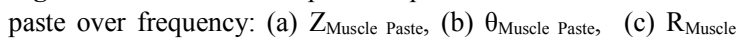
Paste, (d) $\mathrm{X}_{\text {Muscle Paste }}$

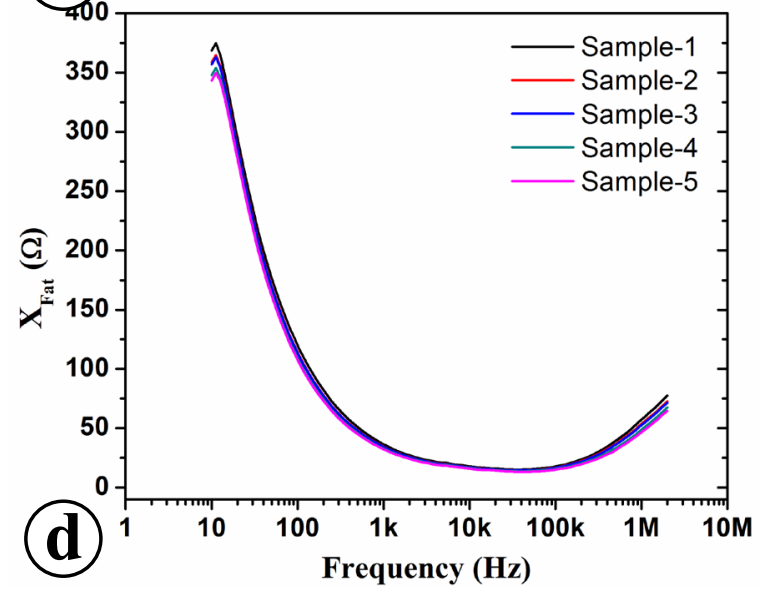

Figure-6: Variation of impedance parameters of chicken tissue over frequency: (a) $Z_{\text {Fat }}$, (b) $\theta_{\text {Fat }}$, (c) $R_{\text {Fat }}$, (d) $X_{\text {Fat }}$ 


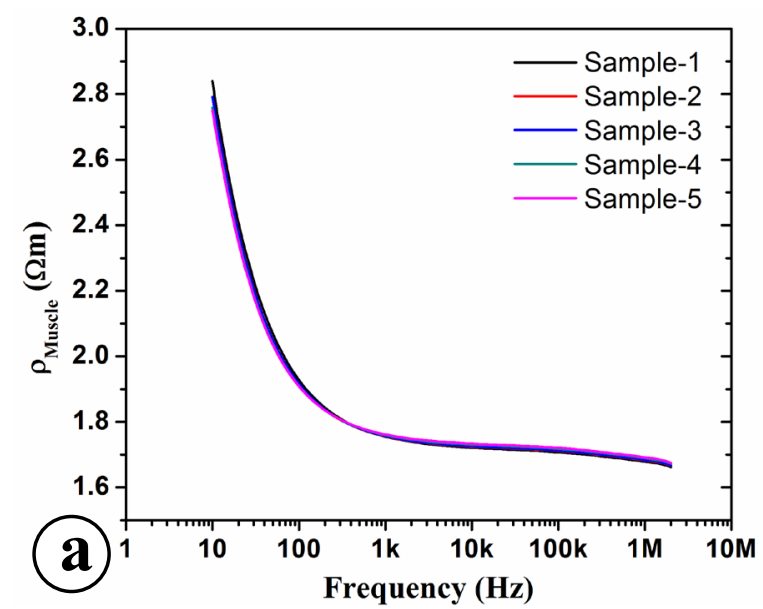

Figure-5a shows that at $2 \mathrm{MHz}$ the $\mathrm{Z}_{\text {Muscle Paste }}$ varies (electrode to electrode variations) from $207.75 \Omega$ to $209.33 \Omega$ (Table-1) whereas the $Z_{\text {Fat }}$ (Fig.-6a) varies from $730.08 \Omega$ to $783.66 \Omega$ (Table-1). Similarly, the percentage variations (variation between highest and lowest frequencies) of $\theta_{\text {Fat }}$ (Fig.-6b), $R_{\text {Fat }}$ (Fig.-6c), $X_{\text {Fat }}$ (Fig.-6d), $\rho_{\text {Fat }}$ (Fig.-8c) and $\sigma_{\text {Fat }}$ (Fig.-8d) are found to be

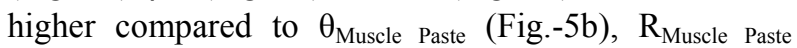
(Fig.-5c), $X_{\text {Muscle Paste }}$ (Fig.-5d), $\rho_{\text {Muscle Paste }}$ (Fig.-8a) and

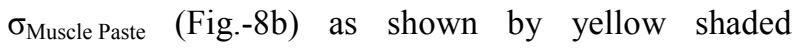
numbers in table-1. It is observed that the variations in Nyquist plots of the fat tissue samples are larger (Fig.-8a-8b) compared to the muscle tissue samples.
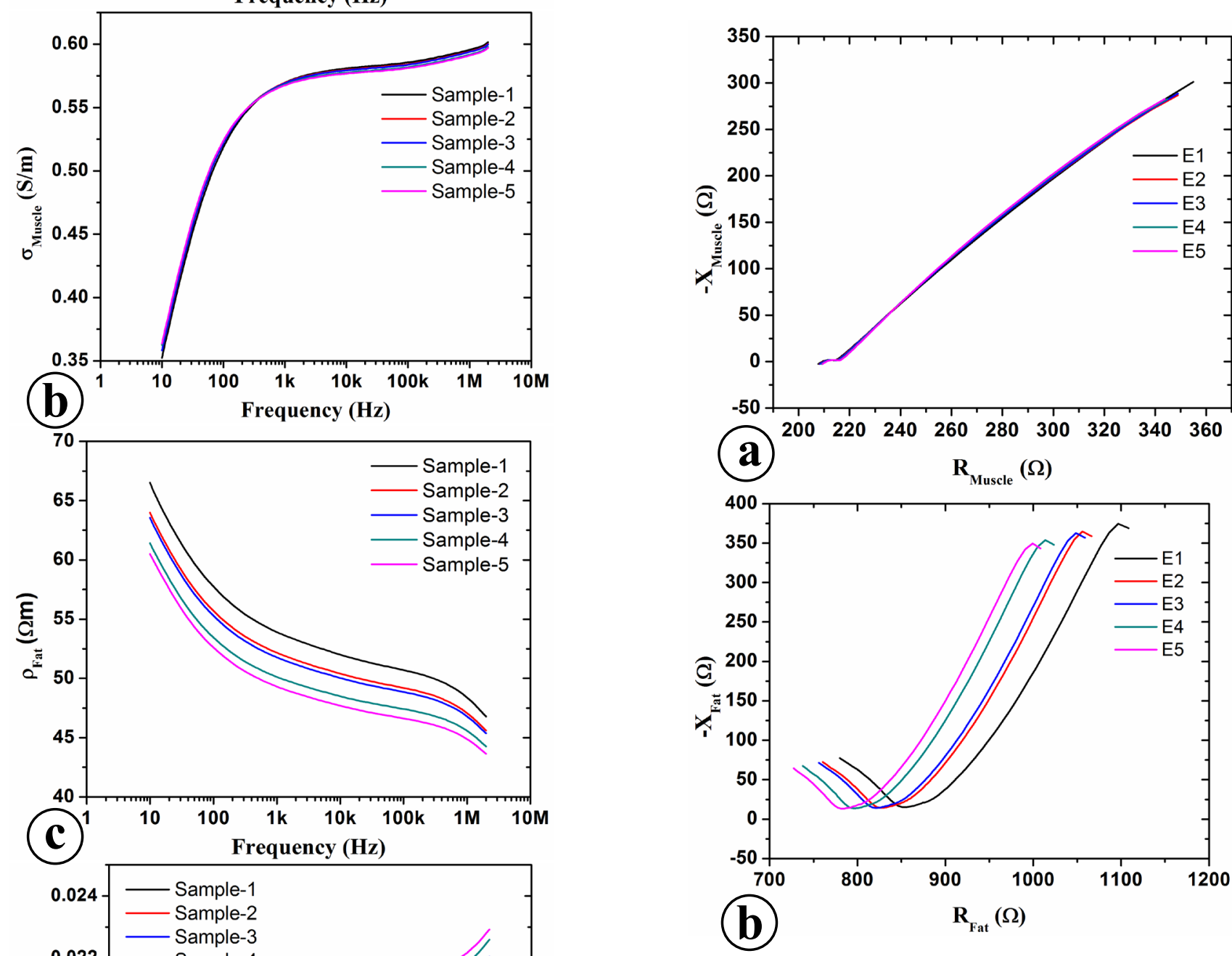

Figure-8: Nyquist plots tissue samples (a) muscle Paste, (b) fat.

Fig.-9a shows that for muscle tissue, the variation in $Z_{\text {Mean }}$ is found between $10 \mathrm{~Hz}-1 \mathrm{kHz}$ whereas it remains almost constant within $1 \mathrm{kHz}-2 \mathrm{MHz}$. On the other hand, for fat tissue, $Z_{\text {Mean }}$ (Fig.-9a) varies throughout the frequency band $(10 \mathrm{~Hz}-2 \mathrm{MHz})$ with a larger variation within $10 \mathrm{~Hz}-1$ $\mathrm{kHz}$. It is observed that for muscle tissue, the variations of $\theta_{\text {Mean }}$ (Fig.-9b), $\mathrm{R}_{\text {Mean }}$ (Fig.-9c), $\mathrm{X}_{\text {Mean }}$ (Fig.-9d), $\rho_{\text {Mean }}$ (Fig.-10a) and $\sigma_{\text {Mean }}$ (Fig.-10b) are comparatively higher in the low frequency range $(10 \mathrm{~Hz}-1 \mathrm{kHz})$ whereas their variations are very low after $1 \mathrm{kHz}$.

Figure-7: Variation of impedance parameters of chicken tissue over frequency: (a) $\rho_{\text {Muscle Paste }}$, (b) $\sigma_{\text {Muscle Paste }}$, (c) $\rho_{\text {Fat }}$, (d) $\sigma_{\text {Fat }}$. 

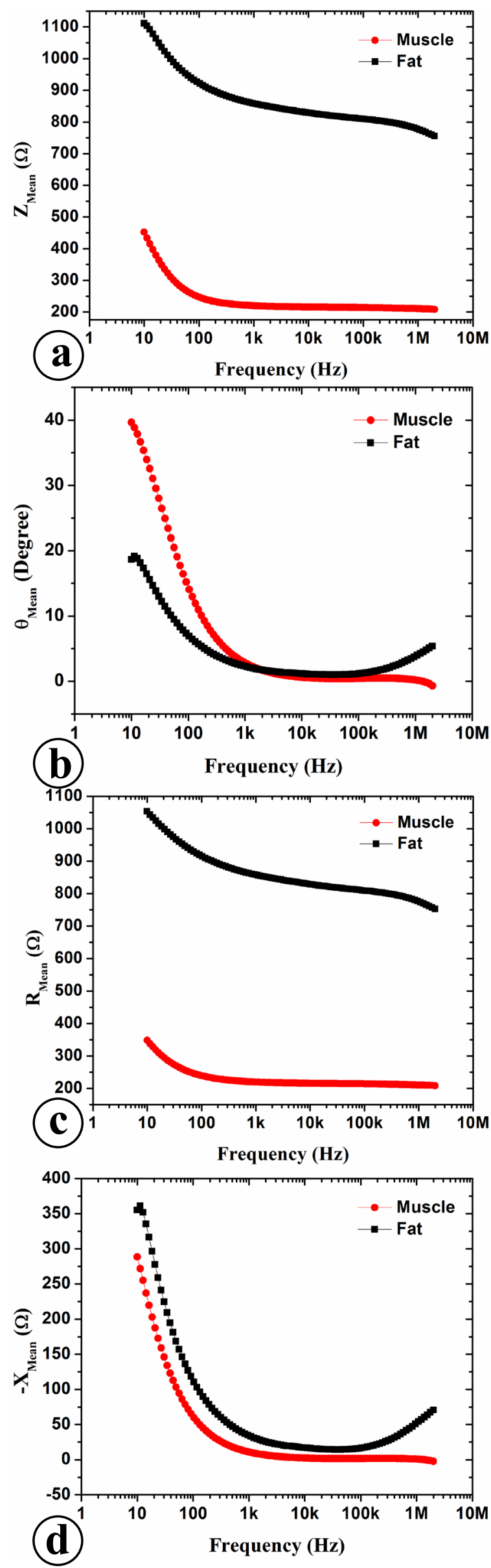

Figure-9: Algebraic mean of the $\mathrm{Z}, \theta, \mathrm{R}$ and $\mathrm{X}$ of chicken muscle tissue paste and fat tissue: (a) Z, (b) $\theta$, (c) R, (d) X
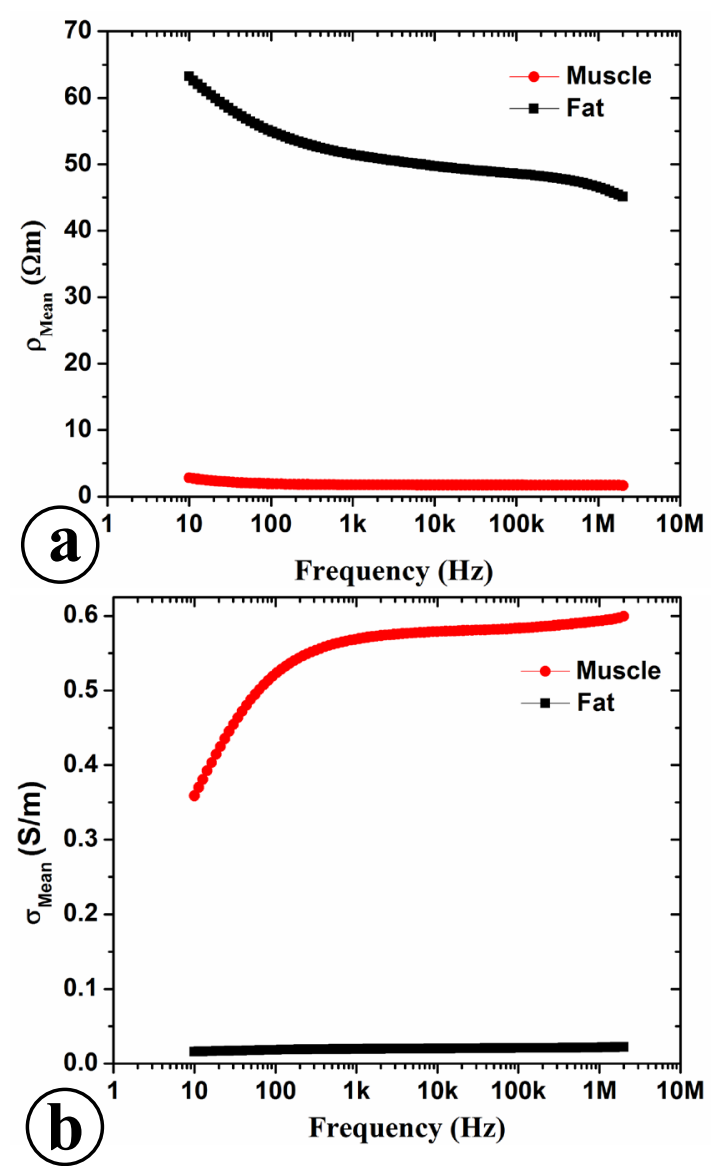

Figure-10: Algebraic mean of the $\rho$ and $\sigma$ of chicken muscle tissue paste and fat tissue: (a) $\rho_{\text {Mean }}$, (b) $\sigma_{\text {Mean }}$

Table-1: Variation of impedance parameters of muscle tissue paste and fat tissue samples $\left(Z_{\text {Muscle Paste }}, \theta_{\text {Muscle Paste }}, R_{\text {Muscle Paste, }}\right.$, $\mathrm{X}_{\text {Muscle Paste }}, \rho_{\text {Muscle Paste, }}, \sigma_{\text {Muscle Paste }}, Z_{\text {Fat }}, \theta_{\text {Fat }}, R_{\text {Fat }}, X_{\text {Fat }}, \rho_{\text {Fat }}$ and $\left.\sigma_{\text {Fat }}.\right)$ for $10 \mathrm{~Hz}$ to $2 \mathrm{MHz}$.

\begin{tabular}{|l|r|r|r|r|r|}
\hline \multicolumn{2}{|l|}{ Parameters } & \multicolumn{1}{l|}{ Min } & \multicolumn{1}{l|}{ Max } & \multicolumn{1}{l|}{ Mean } & \multicolumn{1}{l|}{ Change } \\
\hline $\mathbf{Z}_{\text {Muscle }}$ & $10 \mathrm{~Hz}$ & 445.01 & 465.54 & 455.28 & $4.51 \%$ \\
\cline { 2 - 6 } & $2 \mathrm{MHz}$ & 207.75 & 209.33 & 208.54 & $0.76 \%$ \\
\hline \multirow{2}{*}{$\mathbf{Z}_{\text {Fat }}$} & $10 \mathrm{~Hz}$ & 1065.09 & 1168.15 & 1116.62 & $9.23 \%$ \\
\cline { 2 - 6 } & $2 \mathrm{MHz}$ & 730.08 & 783.66 & 756.87 & $7.08 \%$ \\
\hline $\boldsymbol{\theta}_{\text {Muscle }}$ & $10 \mathrm{~Hz}$ & -40.34 & -39.38 & -39.86 & $2.40 \%$ \\
\cline { 2 - 6 } & $2 \mathrm{MHz}$ & 0.66 & 0.70 & 0.68 & $4.71 \%$ \\
\hline \multirow{3}{*}{$\boldsymbol{\theta}_{\text {Fat }}$} & $10 \mathrm{~Hz}$ & -18.82 & -18.41 & -18.62 & $2.21 \%$ \\
\cline { 2 - 6 } & $2 \mathrm{MHz}$ & -5.67 & -5.08 & -5.38 & $11.04 \%$ \\
\hline $\mathbf{R}_{\text {Muscle }}$ & $10 \mathrm{~Hz}$ & 343.76 & 354.96 & 349.36 & $3.20 \%$ \\
\cline { 2 - 6 } & $2 \mathrm{MHz}$ & 207.73 & 209.32 & 208.52 & $0.76 \%$ \\
\hline $\mathbf{R}_{\text {Fat }}$ & $10 \mathrm{~Hz}$ & 1008.19 & 1108.41 & 1058.30 & $9.47 \%$ \\
\cline { 2 - 6 } & $2 \mathrm{MHz}$ & 727.22 & 779.82 & 753.52 & $6.98 \%$ \\
\hline $\mathbf{X}_{\text {Muscle }}$ & $10 \mathrm{~Hz}$ & 282.60 & 301.22 & 291.91 & $6.38 \%$ \\
\cline { 2 - 6 } & $2 \mathrm{MHz}$ & -2.52 & -2.42 & -2.47 & $3.95 \%$ \\
\hline $\mathbf{X}_{\text {Fat }}$ & $10 \mathrm{~Hz}$ & 343.47 & 368.77 & 356.12 & $7.10 \%$ \\
\cline { 2 - 6 } & $2 \mathrm{MHz}$ & 64.62 & 77.44 & 71.03 & $18.05 \%$ \\
\hline \multirow{2}{*}{$\boldsymbol{\rho}_{\text {Muscle }}$} & $10 \mathrm{~Hz}$ & 2.75 & 2.84 & 2.79 & $3.20 \%$ \\
\cline { 2 - 6 } & $2 \mathrm{MHz}$ & 1.66 & 1.67 & 1.67 & $0.76 \%$ \\
\hline \multirow{3}{*}{$\boldsymbol{\rho}_{\text {Fat }}$} & $10 \mathrm{~Hz}$ & 60.49 & 66.50 & 63.50 & $9.47 \%$ \\
\cline { 2 - 6 } & $2 \mathrm{MHz}$ & 43.63 & 46.79 & 45.21 & $6.98 \%$ \\
\hline \multirow{2}{*}{$\boldsymbol{\sigma}_{\text {Muscle }}$} & $10 \mathrm{~Hz}$ & 0.3522 & 0.3636 & 0.3579 & $3.19 \%$ \\
\cline { 2 - 6 } & $2 \mathrm{MHz}$ & 0.5972 & 0.6017 & 0.5995 & $0.75 \%$ \\
\hline \multirow{2}{*}{$\boldsymbol{\sigma}_{\text {Fat }}$} & $10 \mathrm{~Hz}$ & 0.0150 & 0.0165 & 0.0158 & $9.44 \%$ \\
\cline { 2 - 6 } & $2 \mathrm{MHz}$ & 0.0214 & 0.0229 & 0.0221 & $6.99 \%$ \\
\hline
\end{tabular}


On the contrary, for fat tissue, the $\mathrm{Z}_{\text {Mean }}, \theta_{\text {Mean }}, \mathrm{R}_{\text {Mean }}, \mathrm{X}_{\text {Mean }}$, $\rho_{\text {Mean }}$ and $\sigma_{\text {Mean }}$ are found variable throughout the whole frequency range $(10 \mathrm{~Hz}-2 \mathrm{MHz})$ and the variations of all of them are comparatively larger than the impedance parameters of the muscle tissue.

Nyquist plot of the average of the $Z_{\text {Muscle Paste }}$ and $Z_{\text {Fat }}$ show that for muscle tissue, the Warburg impedance ( $Z_{\text {WMuscle Paste }}$ ) [34] is found between $10 \mathrm{~Hz}$ to $34.2 \mathrm{kHz}$ (Fig.-11a). On the other hand for the fat tissue the Warburg impedance $\left(Z_{\mathrm{WFat}}\right)$ is found between $10 \mathrm{~Hz}-49.5 \mathrm{kHz}$ (Fig.-11b).

It is observed that, STDV of $Z_{\text {Muscle Paste }}$ (Fig.-12a),

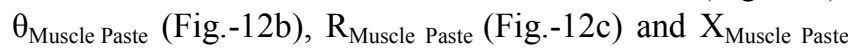
(Fig.-12d) are less than the STDV of the corresponding impedance parameters of the fat tissue. STDV of the ${ }_{\theta \text { Muscle }}$ Paste is found to be higher than the STDV of the $\theta_{\text {Fat }}$ up to $100 \mathrm{kHz}$. It is also observed that the MDR of $Z_{\text {Muscle Paste }}$ (Fig.-13a), $\theta_{\text {Muscle Paste }}$ (Fig.-13b), R $R_{\text {Muscle Paste }}$ (Fig.-13c) and $\mathrm{X}_{\text {Muscle Paste }}$ (Fig.-13d) are higher than the MDR of the corresponding impedance parameters of the fat tissue. MDR of the $\theta_{\text {Muscle Paste }}$ is found to be less than the MDR of the $\theta_{\text {Fat }}$ up to $100 \mathrm{kHz}$. Results show that STDV $\rho_{\text {Muscle Paste }}$

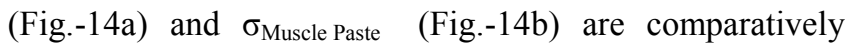
lower than the STDV of $\rho_{\text {Fat }}$ and $\sigma_{\text {Fat }}$. It is also observed that, the MDR of $\rho_{\text {Muscle Paste }}$ (Fig.-15a) and $\sigma_{\text {Muscle Paste }}$ (Fig.-15b) are comparatively higher than the MDR of $\rho_{\text {Fat }}$ and $\sigma_{\text {Fat }}$.
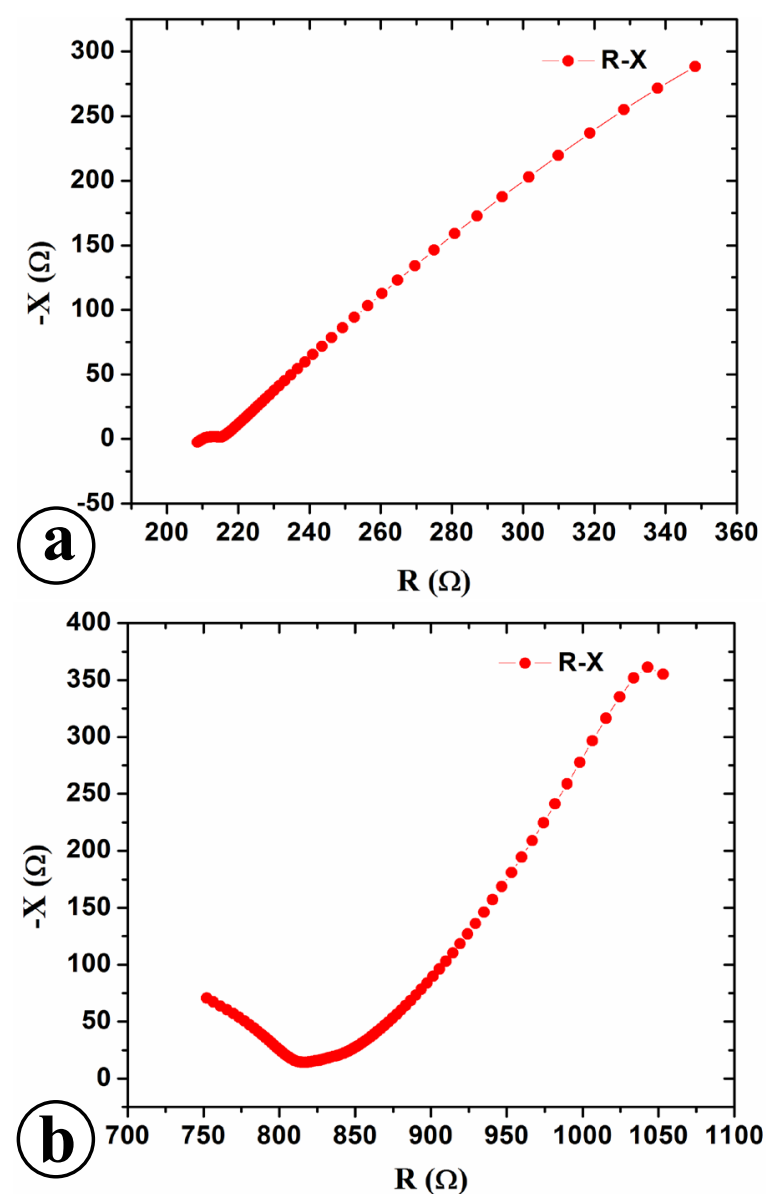

Figure-11: Mean Nyquist plots: (a) $\mathrm{R}_{\text {Muscle Paste }}$ Vs $-\mathrm{X}_{\text {Muscle Paste, }}$ (b) $\mathrm{R}_{\text {Fat }}$ Vs $-\mathrm{X}_{\text {Fat }}$.
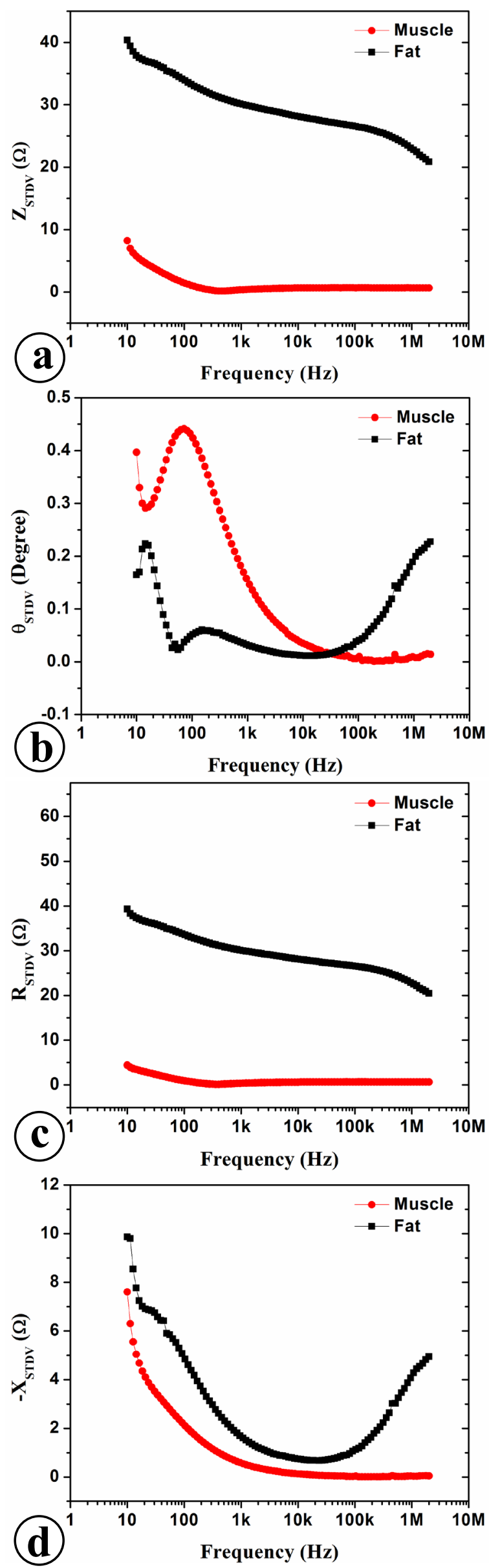

Figure-12: STDV of the impedance parameters of chicken muscle tissue paste and fat tissue: (a) Z, (b) $\theta$, (c) R, (d) X 

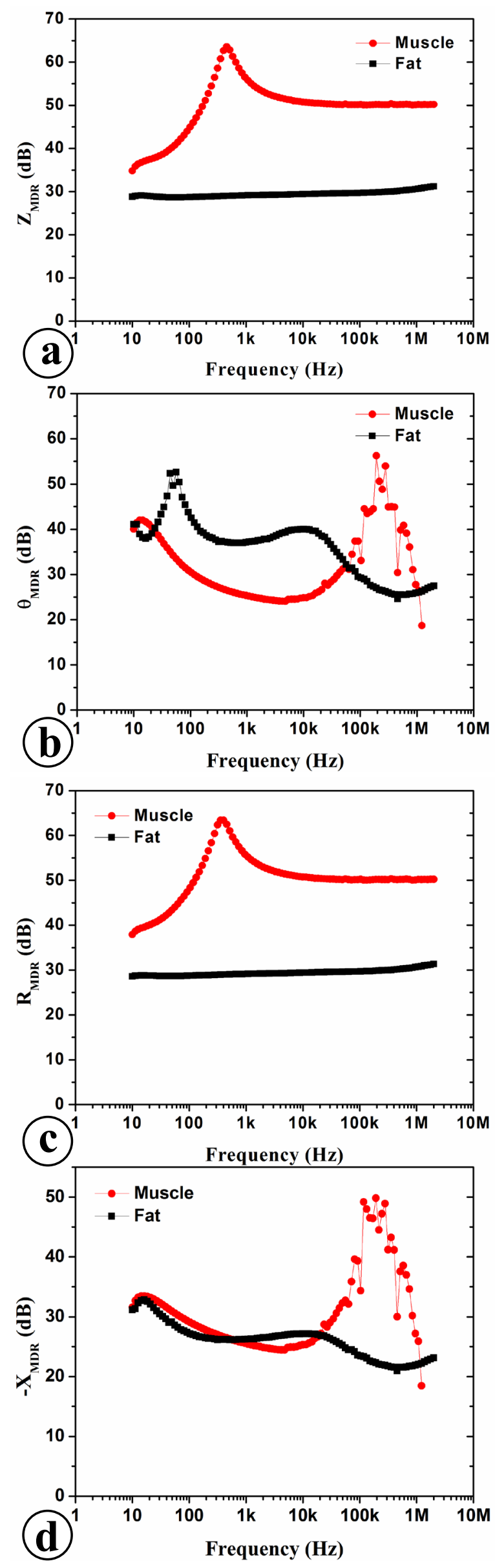

Figure-13: MDR of $Z, \theta, R$ and $X$ of chicken muscle tissue paste and fat tissue: (a) Z, (b) $\theta$, (c) R, (d) X.

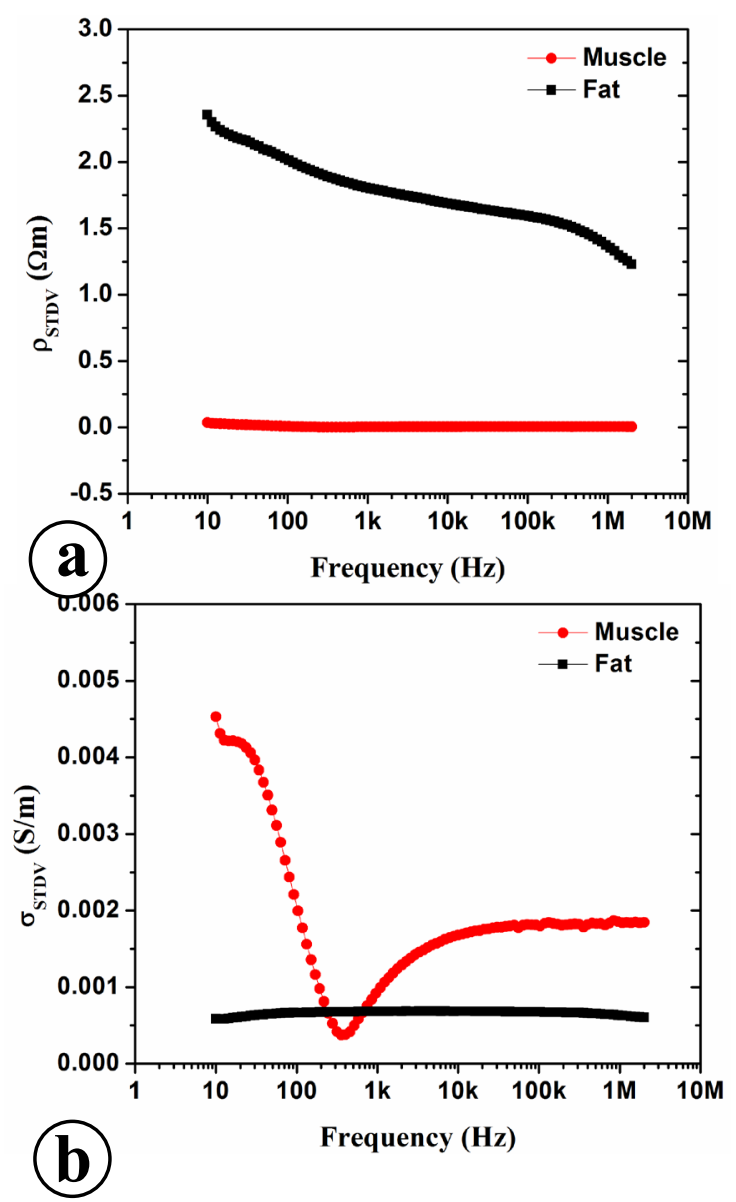

Figure-14: STDV of $\rho$ and $\sigma$ of chicken muscle tissue paste and fat tissue: (a) $\rho$, (b) $\sigma$

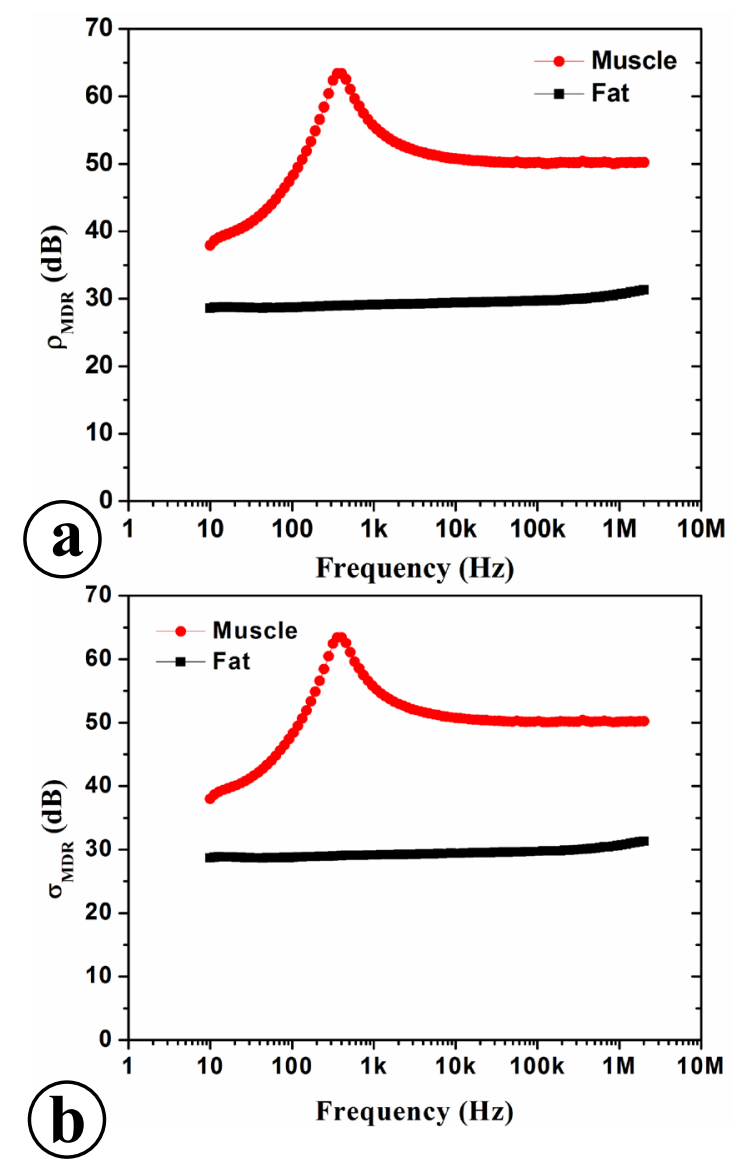

Figure-15: MDR of $\rho$ and $\sigma$ of chicken muscle tissue paste and fat tissue: (a) $\rho$, (b) $\sigma$ 
The EIS between $10 \mathrm{~Hz}$ to $2 \mathrm{MHz}$ fails to show $\alpha, \beta$ and $\gamma$ dispersion [46-49] of chicken muscle tissue paste. This is due to (i) the muscle tissue is grinded to have a paste in which the tissue and cell structure are disturbed and (ii) the lower frequency range $(10 \mathrm{~Hz}$ to $2 \mathrm{MHz})$ in EIS. Hence to obtain the $\alpha$ and $\beta$ dispersion of chicken muscle tissue, EIS is conducted for a rectangular $(15 \mathrm{~mm} \times 20 \mathrm{~mm} \times 20 \mathrm{~mm})$ chicken muscle block (not grinded) within a frequency range of $40 \mathrm{~Hz}$ to $20 \mathrm{MHz}$ using the Agilent 4294A with a $1 \mathrm{~mA}$ constant current signal. EIS is also conducted for a rectangular $(50 \mathrm{~mm} \times 20 \mathrm{~mm} \times 20 \mathrm{~mm})$ chicken muscle paste (not grinded) sample within same frequency range and current signal using the Agilent 4294A.

$\mathrm{Z}, \theta, \mathrm{R}, \mathrm{X}, \rho, \sigma, \mathrm{C}, \varepsilon$ and $\varepsilon_{\mathrm{r}}$ all are calculated and studied for chicken muscle tissue blocks and chicken muscle tissue paste samples. Results show that the muscle tissue block clearly exhibits its $\beta$ dispersion in $0.1-10 \mathrm{MHz}$ frequency range [48-49]. The $\gamma$ dispersion is not obtained as it occurs beyond $1 \mathrm{GHz}$ [49].

In the present study, it is to be noted that there is a difference between the lengths of the chicken tissue muscle block sample $(15 \mathrm{~mm})$ and the chicken tissue muscle paste sample $(50 \mathrm{~mm})$. Hence all the impedance parameters depending on the sample length should be understood with a proper scaling (area of current conduction is fixed for all the samples).

Figure-16 and figure-17 show that, the variations in $\mathrm{Z}_{\text {Muscle Block }}$ (Fig.-16a), $\theta_{\text {Muscle Block }}$ (Fig.-16b), $\mathrm{R}_{\text {Muscle Block }}$

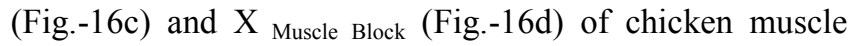
tissue block are larger than the $Z_{\text {Muscle Paste }}$ (Fig.-17a), $\theta_{\text {Muscle }}$ Paste (Fig.-17b), $\mathrm{R}_{\text {Muscle Paste (Fig.-17c) and } \mathrm{X}_{\text {Muscle Paste }}}$ (Fig.-17d), respectively. Results show that the variation in $Z_{\text {Muscle Block }}$ (Fig.-16a) is found throughout the frequency range $(40 \mathrm{~Hz}$ to $20 \mathrm{MHz})$ whereas the variation in $Z_{\text {Muscle }}$ Paste (Fig.-17a) is found only at very low ( $<200 \mathrm{~Hz}$ ) or very high frequencies ( $\mathrm{f}>2 \mathrm{MHz}$ ) due to the electrode polarization. It is observed that the variations in $\rho_{\text {Muscle Block }}$ (Fig.-18a), $\sigma_{\text {Muscle Block }}$ (Fig.-18b), $\mathrm{C}_{\text {Muscle Block }}$ (Fig.-18c) and $\varepsilon_{\mathrm{rMuscle} \text { Block }}$ (Fig.-18d) of the chicken muscle tissue block are

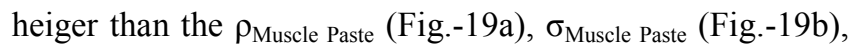
$\mathrm{C}_{\text {Muscle Paste }}$ and $\varepsilon_{\mathrm{rMuscle} \text { Paste, }}$, respectively.

Fig.-16 through Fig.-19 show that the $\alpha$ and $\beta$ dispersions are visible in all the impedance parameters $(Z$, $\theta, \mathrm{R}, \mathrm{X}, \rho, \sigma, \mathrm{C}, \varepsilon$ and $\varepsilon_{\mathrm{r}}$ ) of both the tissue samples, but the dispersions are larger for muscle tissue block compared to the muscle tissue paste.

The Nyquist plot (Fig.-20) [34] obtained for the muscle tissue block demonstrates that the equivalent electric model of the tissue sample contains Warburg impedance [34, 5051] and a constant phase element [50].
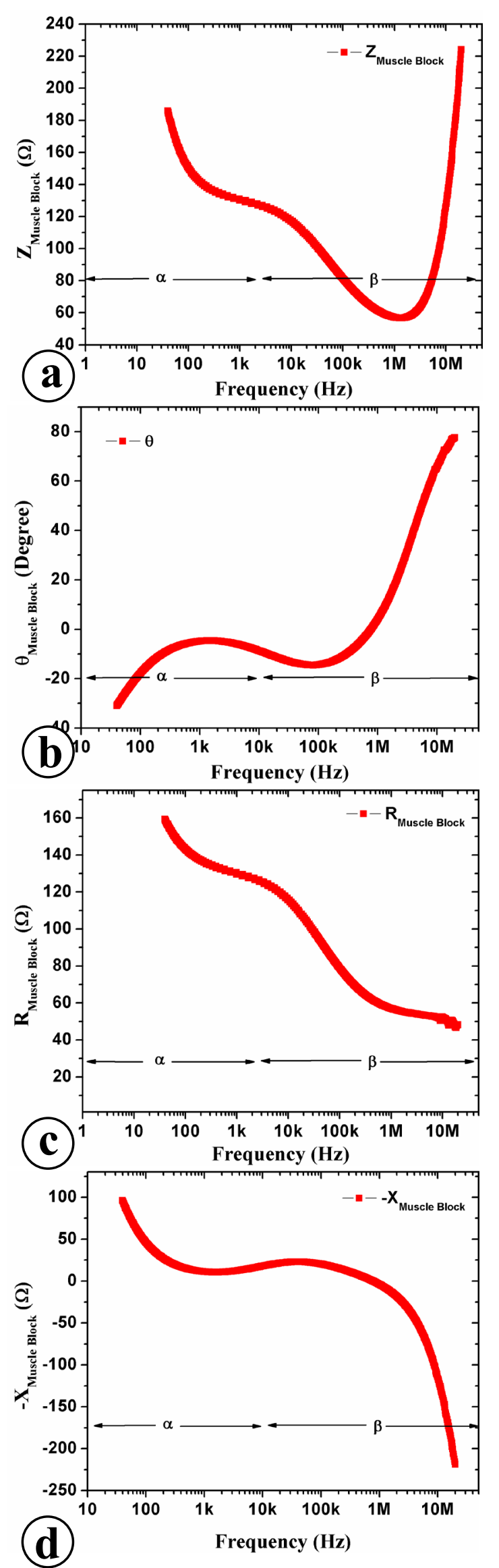

Figure-16: Variations of impedance parameters of chicken muscle tissue block over frequency: (a) $Z_{\text {Muscle Block, (b) }}$

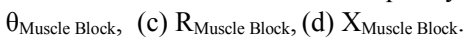



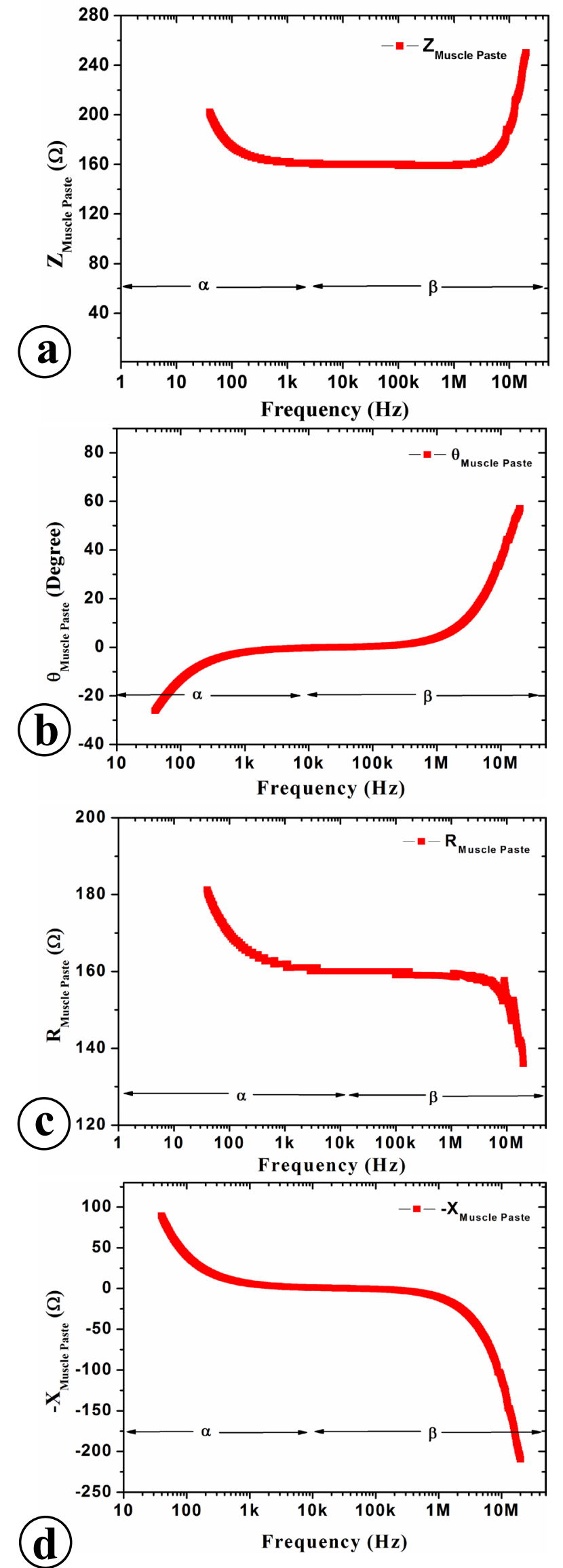

Figure-17: Variations of impedance parameters of chicken muscle tissue paste over frequency: (a) $Z_{\text {Muscle Paste }}$, (b) $\theta_{\text {Muscle Paste }}$, (c) $\mathrm{R}_{\text {Muscle Paste, }}$ (d) $\mathrm{X}_{\text {Muscle Paste. }}$
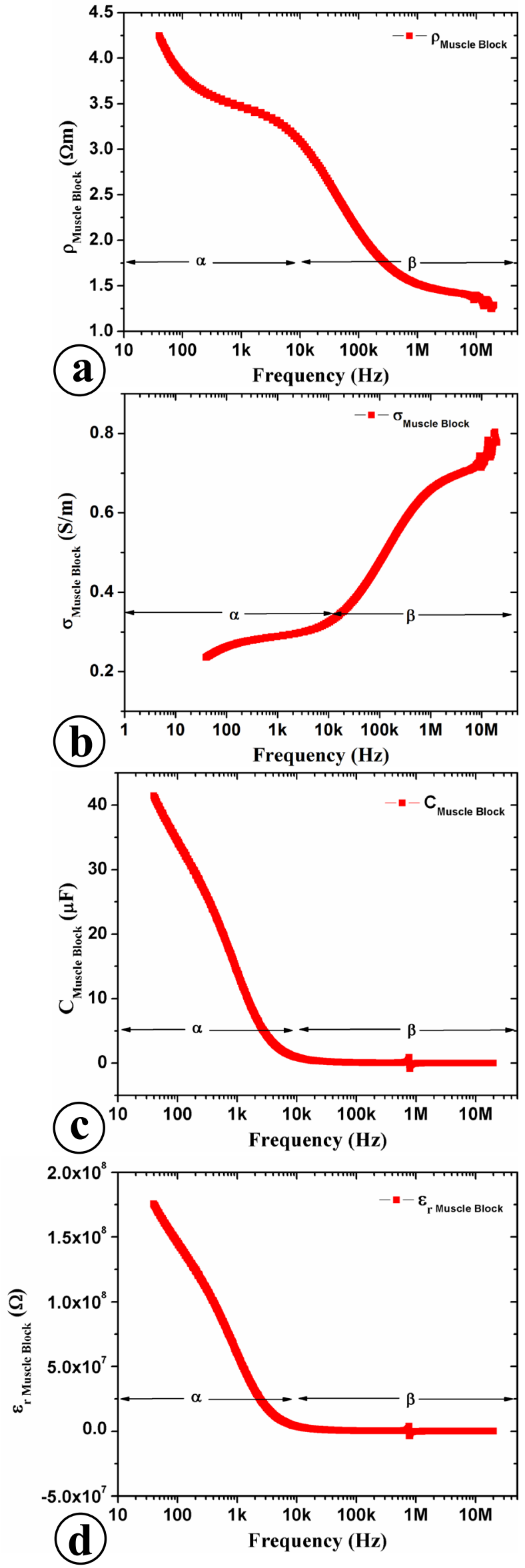

Figure-18: Variations of impedance parameters of chicken muscle tissue block over frequency: (a) $\rho_{\text {Muscle Block, (b) }}$ $\sigma_{\text {Muscle Block}}$, (c) $\mathrm{C}_{\text {Muscle Block }}$, (d) $\varepsilon_{\text {rMuscle Block. }}$. 
As the $\alpha$ and $\beta$ dispersions are larger for the muscle tissue block, the muscle tissue block is found more suitable for the phantom materials of multifrequency EIT compared to the tissue paste. As the muscle tissue block has larger dispersion in a wide range of frequencies, it is more suitable for multifrequency EIT both for low frequency and high frequency EIT. On the contrary, as the $\alpha$ and $\beta$ dispersions are smaller for muscle tissue paste, it can also be used for phantom materials in low frequency EIT.
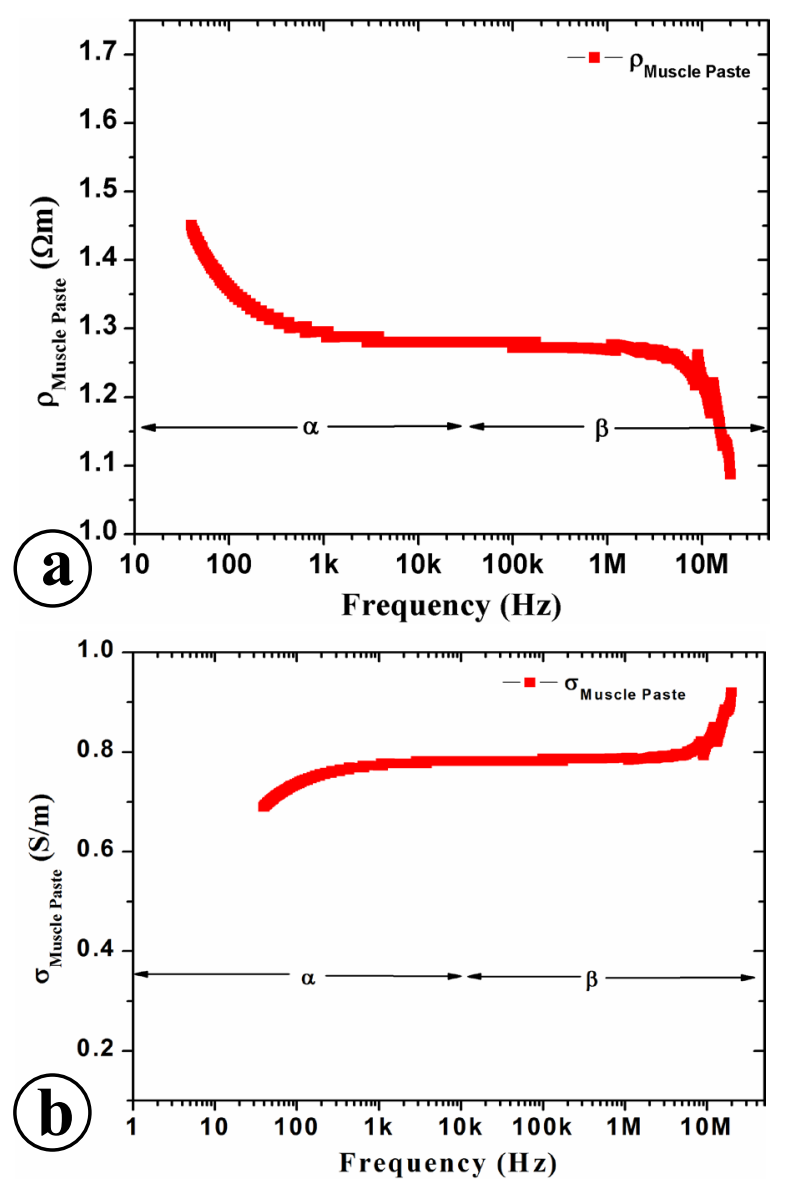

Figure-19: Variations of impedance parameters of chicken muscle tissue paste over frequency: (a) $\rho_{\text {Muscle Paste, }}$ (b) $\sigma_{\text {Muscle Paste }}$.

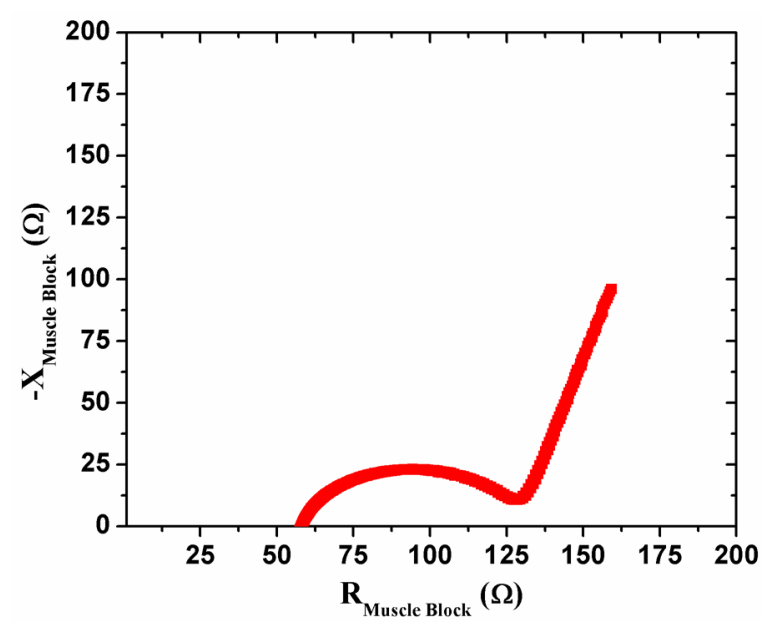

Figure-20: Nyquist plots tissue samples muscle tissue block

\section{Discussion}

Saline phantoms with insulator inhomogeneities cannot mimic the physiological structure of real body tissue as the saline or any other salt solutions are purely resistive, whereas the biological tissues are always found with a complex electrical impedance. Therefore the saline solution and insulator inhomogeneity are not always suitable materials for practical phantoms to study the multifrequency EIT because the response of the purely resistive materials does not change over frequency. In saline insulator phantoms the $\mathrm{NaCl}$ or $\mathrm{KCl}$ solution shows constant response over frequency and the insulator inhomogeneity is a pure high-resistive material. As the animal tissues show a variable response over a wide band of signal frequencies due to their complex physiological and physiochemical structures, they can suitably be used as bathing medium and inhomogeneity in the phantoms of multifrequency EIT systems. Moreover, an efficient assessment of a multifrequency EIT system with a real tissue phantom needs a prior knowledge of the impedance profile of the bathing medium and inhomogeneity. Hence it is essential to study the electrical impedance spectroscopy of biological tissues selected for EIT-phantom materials.

Hence the chicken tissues are proposed as the EIT phantom materials and in this direction EIS studies of broiler chicken muscle tissue blocks, muscle tissue paste and fat tissue are conducted in a wide range of frequencies using impedance analyzers and their impedance profiles are thoroughly studied. For a suitable and fair comparison, EIS of a $\mathrm{KCl}$ solution is also studied and the results are analyzed. It is observed that the conductivity of the $\mathrm{KCl}$ solutions remain constant over the frequency. Therefore it is proved that the $\mathrm{KCl}$ solution is purely resistive and hence it is independent of signal frequency. It is also observed that the $\sigma_{\mathrm{KCl}}$ is a linear function of $\eta_{\mathrm{KCl}}$ and the rate of increase of $\sigma_{\mathrm{KCl}}$ at different frequencies is almost the same up to the $\mathrm{KCl}$ concentration of $1 \%$. Beyond the $\mathrm{KCl}$ concentration of $1 \%$, it is observed that the rate of increase of $\sigma_{\mathrm{KCl}}$ reduces slightly due to the higher ion concentration effect. It is also observed that, beyond the $\eta_{\mathrm{KCl}}$ of $1 \%$, the rate of increase of $\sigma_{\mathrm{KCl}}$ differs from frequency to frequency up to $100 \mathrm{kHz}$. On the other hand, the slopes of the $\sigma_{\mathrm{KCl}}$ curves for different frequencies are found to be the same beyond $100 \mathrm{kHz}$. The reason is that at the higher frequencies the contact impedance of the electrodes is reduced and ion mobility in the $\mathrm{KCl}$ solution increases.

It is observed that the all the impedance parameters $(Z, \theta$, $\mathrm{R}, \mathrm{X}, \rho, \sigma, \mathrm{C}, \varepsilon$ and $\varepsilon_{\mathrm{r}}$ ) of chicken muscle tissue blocks, muscle tissue paste and fat tissue are functions of frequency. Muscle tissue blocks and fat tissue show a wide range of variations over signal frequency whereas the muscle tissue paste shows a very low variation at high frequencies. Hence, chicken muscle tissue and fat tissue are found suitable for phantom materials in multifrequency EIT 
systems. Muscle tissue paste can be used for low frequency EIT or single frequency EIT. It is observed that the sample to sample variation of impedance parameters are found to be smaller in chicken muscle tissue paste and hence it is found to be more homogeneous than the fat tissue. Therefore muscle tissue paste is found more suitable as the phantom bathing medium compared to fat tissue. Fat tissue is found more resistive and offers a wide range of variation in its impedance parameters and hence it is found suitable as the inhomogeneity in multifrequency EIT phantoms.

It is observed that the phantom can be used for 4-5 days if we preserved it in low temperature. But in ambient temperature it deteriorates after a day. Membranes of the cells in the muscle tissue paste are destroyed due to the grinding and therefore the muscle tissue paste shows a very low dispersion at frequencies greater than $1 \mathrm{kHz}$. In the proposed EIT phantoms, the reconstruction parameter is the resistivity which is also frequency dependent and calculated from the real part of the complex impedance and therefore the phase angle is not so important here. Hence, the low phase angle of chicken tissue paste is not a problem for absolute imaging of single frequency static EIT. The EIT phantom with uncrushed tissues (small pieces of tissues) is non uniform and each tissue block will show different frequency responses. Uniform background medium with a chicken tissue block is difficult to make as a single chicken tissue of $150 \mathrm{~mm}$ diameter (diameter of the phantom in our present study) is not available. Non-uniform bathing medium will make the EIT imaging study more complex. Hence a chicken tissue paste is taken, which is uniform all over the background region and hence the entire bathing medium (background region) will show a similar frequency response but different from the frequency response of the inhomogeneity. However, studying a multifrequency EIT system needs a medium showing a large dispersion in the high frequency range. In this direction a detailed study with fresh muscle tissue blocks is conducted within a frequency range of $40 \mathrm{~Hz}$ to $20 \mathrm{MHz}$ using the Agilent 4294A with a $1 \mathrm{~mA}$ constant current signal. Z, $\theta, \mathrm{R}, \mathrm{X}, \rho, \sigma, \mathrm{C}, \varepsilon$ and $\varepsilon_{\mathrm{r}}$ all are calculated and studied for chicken muscle tissue blocks and chicken muscle tissue paste samples. Results show that the muscle tissue block clearly exhibits its $\beta$ dispersion in the $0.1-10 \mathrm{MHz}$ frequency range. The $\gamma$ dispersion is not obtained as it occurs beyond $1 \mathrm{GHz}$. Results also show that the $\alpha$ and $\beta$ dispersions are visible in all the parameters of both the tissue samples, but the dispersions are larger for the muscle tissue block. The Nyquist plot obtained for the muscle tissue block demonstrates that the equivalent electric model of the tissue sample contains Warburg impedance and a constant phase element. Hence, the muscle tissue block is suitable for multifrequency EIT compared to the tissue paste. As the muscle tissue block has larger dispersion in the high frequency range and hence it is more suitable for multifrequency EIT as well as for high frequency EIT. Collectively it is concluded that the chicken muscle tissue and fat tissue can be successfully used as the bathing medium and inhomogeneity (though the reverse can also be done), respectively, in the phantoms suitable for impedance imaging in multifrequency EIT.

\section{Conclusions}

EIS of broiler chicken muscle tissue paste, chicken muscle tissue blocks and broiler chicken fat tissue are conducted in a wide range of frequencies using impedance analyzers and their impedance profiles are thoroughly studied. Chicken tissues showed a variable response over a wide band of signal frequencies due to their complex physiological and physiochemical structures and hence they are found suitable as phantom materials in multifrequency medical EIT systems. It is found that the all the impedance parameters $\left(\mathrm{Z}, \theta, \mathrm{R}, \mathrm{X}, \rho, \sigma, \mathrm{C}, \varepsilon\right.$ and $\varepsilon_{\mathrm{r}}$ ) of chicken tissue samples studied are functions of frequency. Moreover the sample to sample variation of impedance parameters is found to be less in chicken muscle tissue paste and hence it is found more homogeneous than the fat tissue. Therefore muscle tissue paste is found more suitable as the phantom bathing medium compared to fat tissue. Fat tissue is found more resistive and offers a wide range of variation in its impedance parameters and hence it is found suitable as the inhomogeneity in multifrequency EIT phantoms. The variations in the impedance parameters of muscle tissue blocks are found to be larger compared to the tissue paste as the cell membrane structures are destroyed during grinding. Results also show that the $\alpha$ and $\beta$ dispersions are visible in all the parameters of both the tissue samples, but the dispersions are larger for the muscle tissue block. The Nyquist plot obtained for the muscle tissue block demonstrates that the equivalent electric model of the tissue sample contains Warburg impedance and a constant phase element. On the contrary, it is observed that the conductivity of the $\mathrm{KCl}$ solutions of all concentrations is independent of signal frequency and $\sigma_{\mathrm{KCl}}$ is a linear function of $\eta_{\mathrm{KCl}}$. Finally it is concluded that the chicken muscle tissue and fat tissue can be used successfully as the bathing medium and inhomogeneity in the phantoms suitable for impedance imaging in multifrequency EIT.

\section{References}

1. Holder DS, Hanquan Y and Rao A, Some practical biological phantoms for calibrating multifrequency electrical impedance tomography, Physiol. Meas. 1996; 17: A167-A177. doi:10.1088/0967-3334/17/4A/021

2. Bera TK and Nagaraju J, Resistivity Imaging of A Reconfigurable Phantom With Circular Inhomogeneities in 2D-Electrical Impedance Tomography, Measurement. 2011; 44(3): 518-526. doi:10.1016/j.measurement.2010.11.015

3. Soni NK, Dehghani H, Hartov A and Paulsen KD, A novel data calibration scheme for electrical impedance tomography, Physiol. Meas. 2003; 24: 421-435. doi:10.1088/0967-3334/24/2/354 
4. Bera TK and Nagaraju J, A Simple Instrumentation Calibration Technique for Electrical Impedance Tomography (EIT) Using A 16 Electrode Phantom, Proceedings of The Fifth Annual IEEE Conference on Automation Science and Engineering (IEEE CASE 2009), Bangalore, August 22 to 25, 2009; pp. 347-352. doi:10.1109/COASE.2009.5234117

5. Ahn S, Jun SC, Seo JK, Lee J, Woo EJ and Holder D, Frequency-difference electrical impedance tomography: phantom imaging experiments, Journal of Physics: Conference Series. 2010; 224: 012152. doi:10.1088/1742-6596/224/1/012152

6. Bera TK and Nagaraju J, A Reconfigurable Practical Phantom for Studying the 2 D Electrical Impedance Tomography (EIT) Using a FEM Based Forward Solver, 10th International Conference on Biomedical Applications of Electrical Impedance Tomography (EIT 2009), School of Mathematics, The University of Manchester, UK. 16th-19th June 2009. URL:http://www.maths.manchester.ac.uk/eit2009 /abstracts/bera.pdf

7. Bera TK and Nagaraju J, A FEM-Based Forward Solver for Studying the Forward Problem of Electrical Impedance Tomography (EIT) with A Practical Biological Phantom, Proceedings of IEEE International Advance Computing Conference' 2009 (IEEE IACC - 2009), Patiala, Punjab, India. 6th-7th March 2009; pp 1375 - 1381. doi:10.1109/IADCC.2009.4809217

8. Bera TK and Nagaraju J, Studying the Boundary Data Profile of A Practical Phantom for Medical Electrical Impedance Tomography with Different Electrode Geometries, Proceedings of The World Congress on Medical Physics and Biomedical Engineering-2009 Sept 7-12, 2009, Munich, Germany, IFMBE Proceedings 25/II. 2009; pp. 925-929. doi:10.1007/978-3-642-03879-2 258

9. Bera TK and Nagaraju J, A Stainless Steel Electrode Phantom to Study the Forward Problem of Electrical Impedance Tomography (EIT), Sensors \& Transducers Journal. 2009; 104(5): 33-40.

10. Griffiths $\mathrm{H}$, A phantom for electrical impedance tomography, Clin. Phys. Physiol. Meas. 1988; 9(Suppl. A): 15-20. doi:10.1088/0143-0815/9/4A/003

11. Webster JG, Electrical impedance tomography. Adam Hilger Series of Biomedical Engineering, Adam Hilger, New York, USA. 1990.

12. Cheney M, Isaacson D, Newell JC, Electrical Impedance Tomography, SIAM Review, 1999; 41(1): 85-101. doi:10.1137/S0036144598333613

13. Bayford RH, Bioimpedance Tomography (Electrical Impedance Tomography), Annual Review of Biomedical Engineering. 2006; 8: 63-91. doi:10.1146/annurev.bioeng.8.061505.095716
14. Denyer CWL, Electronics for Real-Time and ThreeDimensional Electrical Impedance Tomographs, PhD Thesis, Oxford Brookes University, 1996.

15. Holder DS, Electrical impedance tomography: methods, history and applications (Series in Medical Physics and Biomedical Engineering), 1st Ed. Institute of Physics Publishing Ltd., UK. 2005.

16. Borcea L, Electrical impedance tomography, Topical Review, Inverse Problems. 2002; 18: R99-R136. doi:10.1088/0266-5611/18/6/201

17. Bera TK and Nagaraju J, A Study of Practical Biological Phantoms with Simple Instrumentation for Electrical Impedance Tomography (EIT), Proceedings of IEEE International Instrumentation and Measurement Technology Conference (I2MTC2009), Singapore, 5th - 7th May, 2009; pp 511-516. doi:10.1109/IMTC.2009.5168503

18. Bera TK and Nagaraju J, A Multifrequency Constant Current Source for Medical Electrical Impedance Tomography, Proceedings of the IEEE International Conference on Systems in Medicine and Biology 2010 (IEEE ICSMB 2010), Kharagpur, India, 16th-18th Dec'2010; pp-290-295. doi:10.1109/ICSMB.2010.5735387

19. Lionheart WRB, EIT reconstruction algorithms: pitfalls, challenges and recent developments, Review Article, Physiol. Meas. 2004; 25: 125-142. PII: S0967-3334(04)70421-9. doi: $10.1088 / 0967-3334 / 25 / 1 / 021$

20. Graham BM, Enhancements in Electrical Impedance Tomography (EIT) Image Reconstruction for 3D Lung Imaging, PhD thesis, University of Ottawa, April 2007.

21. Yorkey TJ, Comparing reconstruction methods for electrical impedance tomography, $\mathrm{PhD}$ thesis, University of. Wisconsin at Madison, Madison, WI 53706, 1986.

22. Robitaille N, Guardo R, Maurice I, Hartinger AE and Gagnon $\mathrm{H}$, A multi-frequency EIT system design based on telecommunication signal processors, Physiol. Meas. 2009; 30: S57-S71. doi:10.1088/0967-3334/30/6/S04

23. Goharian M, Soleimani M, Jegatheesan A, Chin K and Moran GR, A DSP Based Multi-Frequency 3D Electrical Impedance Tomography System. Annals of Biomedical Engineering. 2008; 36: 1594-1603. doi:10.1007/s10439-008-9537-5

24. Romsauerova A, McEwan A, Horesh L, Yerworth R, Bayford RH, and Holder DS, Multi-frequency electrical impedance tomography (EIT) of the adult human head: initial findings in brain tumours, arteriovenous malformations and chronic stroke, development of an analysis method and calibration, Physiol. Meas. 2006; 27: S147-S161. doi:10.1088/0967-3334/27/5/S13

25. Ackmann JJ, Complex Bioelectric Impedance Measurement System for the Frequency Range from $5 \mathrm{~Hz}$ to $1 \mathrm{MHz}$, Annals of Biomedical Engineering. 1993; 21:135-146. doi:10.1007/BF02367609 
26. Ackmann JJ, Seitz MA., Methods of complex impedance measurements in biologic tissue, Crit Rev Biomed Eng. 1984; 11(4): 281-311.

27. Cha K, Chertow GM, Gonzalez J, Lazarus JM, and Wilmore DW, Multifrequency bioelectrical impedance estimates the distribution of body water, J Appl Physiol. 1995; 79:13161319.

28. Mouritsen OG, and Bloom M, Models of Lipid-Protein Interactions in Membranes, Annual Review of Biophysics and Biomolecular Structure. 1993; 22: 145-171. doi:10.1146/annurev.bb.22.060193.001045

29. Kyle UG, Bosaeus I, De Lorenzo AD, Deurenberg P, Elia M, G!omez JM, Heitmann BL, Kent-Smith L, Melchior JC, Pirlich M, Scharfetter H, Schols AMWJ, Pichard C, Bioelectrical impedance analysis - part I: review of principles and methods, Clinical Nutrition. 2004; 23: 1226-1243. doi:10.1016/j.clnu.2004.06.004

30. Kyle UG, Bosaeus I, De Lorenzo AD, Deurenberg P, Elia M, Go'mez JM, Heitmann BL, Kent-Smith L, Melchior JC, Pirlich M, Scharfetter H, Schols AMWJ, Pichard C, Bioelectrical impedance analysis-part II: utilization in clinical practice, Clinical Nutrition. 2004; 23: 1430-1453. doi:10.1016/j.clnu.2004.09.012

31. Gudivaka R, Schoeller DA, Kushner RF, and Bolt MJG, Single and multifrequency models for bioelectrical impedance analysis of body water compartments, Journal of Applied Physiology. 1999; 87(3): 1087-1096.

32. Kahraman A, Hilsenbeck J, Nyga M, Ertle J, Wree A, Plauth M, Gerken G, Canbay AE, Bioelectrical impedance analysis in clinical practice: implications for hepatitis $\mathrm{C}$ therapy BIA and hepatitis C, Virology Journal. 2010; 7: 191. doi:10.1186/1743-422X-7-191

33. Orazem ME, Tribollet B, Electrochemical Impedance Spectroscopy (The ECS Series of Texts and Monographs), Wiley-Interscience, 2008.

34. Macdonald RJ, Impedance Spectroscopy, Annals of Biomedical Engineering. 1992; 20: 289-305. doi:10.1007/BF02368532

35. Houssin T, Follet J, Follet A, Dei-Cas E, Senez V, Label-free analysis of water-polluting parasite by electrochemical impedance spectroscopy, Article, Biosensors and Bioelectronics. 2010; 25(5): 1122-1129. doi:10.1016/j.bios.2009.09.039

36. Scrymgeour D. A., Highstrete C., Lee Y. J., Julia W. P. Hsu, and Lee M., High frequency impedance spectroscopy on $\mathrm{ZnO}$ nanorod arrays, Journal of Applied Physics. 2010; 107: 064312. doi: $10.1063 / 1.3319555$

37. Nielsen J, Jacobsen T, Current distribution effects in AC impedance spectroscopy of electroceramic point contact and thin film model electrodes, Electrochimica Acta. 2010; 55(21): 6248-6254. doi:10.1016/j.electacta.2009.11.028
38. Wu J, Ben Y and Chang HC, Particle detection by electrical impedance spectroscopy with asymmetric-polarization AC electroosmotic trapping, Microfluid Nanofluid. 2005; 1: 161167. doi:10.1007/s10404-004-0024-5

39. Ayliffe HE, Frazier AB and Rabbitt RD, Electric Impedance Spectroscopy Using Microchannels with Integrated Metal Electrodes, IEEE Journal of Microelectromechanical Systems. 1999; 8(1): 50-57. doi:10.1109/84.749402

40. Torrents JM, Juan-Garcia P and Aguado A, Electrical impedance spectroscopy as a technique for the surveillance of civil engineering structures: considerations on the galvanic insulation of samples, Meas. Sci. Technol. 2007; 18: 19581962. doi:10.1088/0957-0233/18/7/023

41. Repo T, Paine DH and Taylor AG, Electrical impedance spectroscopy in relation to seed viability and moisture content in snap bean (Phaseolus vulgaris L.), Seed Science Research. 2002; 12: 17-29, doi:10.1079/SSR200194

42. Repo T, Laukkanen J and Silvennoinen R, Measurement of the Tree Root Growth Using Electrical Impedance Spectroscopy, Silva Fennica. 2005; 39(2): 159-166.

43. Maxwell JC, A Treatise on Electricity \& Magnetism, vol. 1, London, Oxford Univ. Press. 1892, Chap. 10.

44. Price LRR, Electrical Impedance Computed Tomography (ICT): A New CT Imaging Technique, IEEE Transactions on Nuclear Science. 1979; NS-26(2): 2736-2739. doi:10.1109/TNS.1979.4330526

45. Cole KS, Electric phase angle of cell membranes, J Gen Physiol. 1932; 15: 641-649. doi:10.1085/jgp.15.6.641

46. Schwan HP, Electrical properties of tissues and cell suspensions: mechanisms and models, Proceedings of 16th Annual International Conference of the IEEE Engineering in Medicine and Biology Society. 1994; 1: A70-A71.

47. Miklavcic D, Pavselj N and Hart FX, Electric Properties of Tissues, Wiley Encyclopedia of Biomedical Engineering, John Wiley \& Sons, Inc. 2006, pp.-1-12.

48. Metherall P, Three Dimensional Electrical Impedance Tomography of the Human Thorax, PhD Thesis, University of Sheffield, UK, January 1998.

49. The Biomedical Engineering Handbook: Second Edition, CRC Press. 2000, Chapter-89.

50. Barsoukov E and Macdonald JR, Impedance Spectroscopy: Theory, Experiment, and Applications, Second Edition, John Wiley \& Sons, Inc., 2005, Chapter-1, pp-22.

51. Schwan HP, Linear and nonlinear electrode polarization and biological materials, Annals of Biomedical Engineering. 1992; 20: 269-288. doi:10.1007/BF02368531 